\title{
Changes in soil organic carbon storage predicted by Earth system models during the 21 st century
}

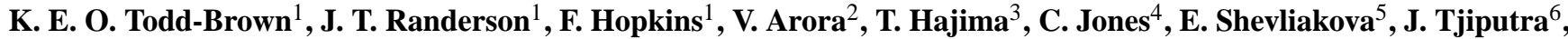 \\ E. Volodin ${ }^{7}$, T. Wu ${ }^{8}$, Q. Zhang ${ }^{9}$, and S. D. Allison ${ }^{1,10}$ \\ ${ }^{1}$ Department of Earth System Science, University of California, Irvine, California, USA \\ ${ }^{2}$ Canadian Centre for Climate Modelling and Analysis, Environment Canada, University of Victoria, Victoria, British \\ Columbia, Canada \\ ${ }^{3}$ Japan Agency for Marine-Earth Science and Technology, Yokohama, Japan \\ ${ }^{4}$ Met Office Hadley Centre, Exeter, UK \\ ${ }^{5}$ Department of Ecology and Evolutionary Biology, Princeton University, Princeton, New Jersey, USA \\ ${ }^{6}$ Uni Climate, Uni Research AS and Bjerknes Centre for Climate Research, Bergen, Norway \\ ${ }^{7}$ Institute of Numerical Mathematics, Russian Academy of Sciences, Moscow, Russia \\ ${ }^{8}$ Beijing Climate Center, China Meteorological Administration, Beijing, China \\ ${ }^{9}$ College for Global Change and Earth System Science, Beijing Normal University, Beijing, China \\ ${ }^{10}$ Ecology and Evolutionary Biology Department, University of California, Irvine, California, USA
}

Correspondence to: K. E. O. Todd-Brown (ktoddbro@uci.edu)

Received: 11 November 2013 - Published in Biogeosciences Discuss.: 4 December 2013

Revised: 21 February 2014 - Accepted: 4 March 2014 - Published: 25 April 2014

\begin{abstract}
Soil is currently thought to be a sink for carbon; however, the response of this sink to increasing levels of atmospheric carbon dioxide and climate change is uncertain. In this study, we analyzed soil organic carbon (SOC) changes from 11 Earth system models (ESMs) contributing simulations to the Coupled Model Intercomparison Project Phase 5 (CMIP5). We used a reduced complexity model based on temperature and moisture sensitivities to analyze the drivers of SOC change for the historical and high radiative forcing (RCP 8.5) scenarios between 1850 and 2100. ESM estimates of SOC changed over the 21 st century (2090-2099 minus 1997-2006) ranging from a loss of $72 \mathrm{PgC}$ to a gain of $253 \mathrm{PgC}$ with a multi-model mean gain of $65 \mathrm{Pg} \mathrm{C}$. Many ESMs simulated large changes in highlatitude SOC that ranged from losses of $37 \mathrm{Pg} \mathrm{C}$ to gains of $146 \mathrm{PgC}$ with a multi-model mean gain of $39 \mathrm{Pg} \mathrm{C}$ across tundra and boreal biomes. All ESMs showed cumulative increases in global NPP (11 to 59\%) and decreases in SOC turnover times (15 to $28 \%$ ) over the 21 st century. Most of the model-to-model variation in SOC change was explained by initial SOC stocks combined with the relative changes in soil inputs and decomposition rates $\left(R^{2}=0.89, p<0.01\right)$.
\end{abstract}

Between models, increases in decomposition rate were well explained by a combination of initial decomposition rate, ESM-specific $Q_{10}$-factors, and changes in soil temperature $\left(R^{2}=0.80, p<0.01\right)$. All SOC changes depended on sustained increases in NPP with global change (primarily driven by increasing $\mathrm{CO}_{2}$ ). Many ESMs simulated large accumulations of SOC in high-latitude biomes that are not consistent with empirical studies. Most ESMs poorly represented permafrost dynamics and omitted potential constraints on SOC storage, such as priming effects, nutrient availability, mineral surface stabilization, and aggregate formation. Future models that represent these constraints are likely to estimate smaller increases in SOC storage over the 21st century.

\section{Introduction}

The global pool of soil organic carbon (SOC) is large relative to atmospheric $\mathrm{CO}_{2}$ (Jobbagy and Jackson, 2000), and changes in soil-atmosphere fluxes of carbon could generate either a positive or negative feedback to climate over the next century. For example, the contemporary soil carbon 
sink in forests is estimated to be approximately $0.9 \mathrm{Pg} \mathrm{C} \mathrm{yr}^{-1}$ (Pan et al., 2011). However, uncertainties in the response of soil inputs and heterotrophic respiration to global change drivers, along with difficulties in measuring heterogeneous SOC pools, lead to relatively large uncertainties in belowground flux estimates (Houghton, 2003; Le Quéré et al., 2009). The balance of SOC over the next century is even less certain (Friedlingstein et al., 2006). Much of this uncertainty is due to the environmental sensitivities of SOC input and output fluxes that depend on environmental variables and will likely change with climate over the next century (Giorgi, 2006).

Net primary production (NPP) provides the primary input of carbon to soil and is sensitive to climate. NPP generally increases with temperature, moisture, and $\mathrm{CO}_{2}$ up to some maximum, in turn providing increased carbon inputs to soil (Chapin and Eviner, 2007; Körner, 2006). Free-air $\mathrm{CO}_{2}$ enrichment (FACE) studies have shown that NPP increases by $23 \%$ on average across forest ecosystems in response to $\mathrm{CO}_{2}$ increases from 365 to 550-580 ppm (Norby et al., 2005). Similar increases in NPP have been observed in shrub- and grassland-elevated $\mathrm{CO}_{2}$ experiments (De Graaff et al., 2006; Hungate et al., 2013). However, increases in NPP may be constrained by available nutrients; the theory of progressive nutrient limitation posits that NPP responses to elevated $\mathrm{CO}_{2}$ will be limited by the supply of soil nutrients, particularly nitrogen (Hungate et al., 2009; Luo et al., 2004; Norby and Zak, 2011; Norby et al., 2010; Nowak et al., 2004).

In addition, it remains unclear whether increases in NPP will translate into increased SOC storage. FACE studies often observe no change in SOC despite increased NPP, possibly due to increased loss rates of $\mathrm{C}$ inputs (Hofmockel et al., 2011; Hoosbeek and Scarascia-Mugnozza, 2009; Phillips et al., 2012) or increased decomposition of SOC through the priming effect (Carney et al., 2007; Cheng et al., 2014; Talhelm et al., 2009). With priming, fresh carbon inputs associated with increasing NPP stimulate the microbial decomposition of SOC, thereby preventing SOC accumulation (Fontaine et al., 2004; Hungate et al., 2013; Kuzyakov et al., 2000; Phillips et al., 2011; Wieder et al., 2014). Alternatively, SOC accumulation under elevated $\mathrm{CO}_{2}$ may be difficult to measure due to spatial heterogeneity in SOC pools and the short timescale of the experiments relative to soil turnover times (Billings et al., 2010; Schlesinger and Lichter, 2001).

Heterotrophic respiration is the primary loss pathway for SOC and is also sensitive to climate change. Heterotrophic respiration generally increases with temperature (Davidson and Janssens, 2006) and moisture levels in well-drained soils (Cook and Orchard, 2008). Many studies have hypothesized that rising temperatures will increase SOC losses through decreased soil turnover times (Davidson and Janssens, 2006; Lloyd and Taylor, 1994). Such changes should increase heterotrophic respiration, especially in the high northern latitudes (Schuur et al., 2008), and contribute to increases in global atmospheric $\mathrm{CO}_{2}$ (Koven et al., 2011). However, other effects like aggregate formation and mineral-organic interactions could stabilize SOC, limiting the response to increased temperature (Dungait et al., 2012; Six et al., 2002; Torn et al., 1997).

Earth system models (ESMs) are the primary tools for predicting climate impacts on carbon storage at the global scale. The Coupled Model Intercomparison Project, currently in its 5th phase (CMIP5), enables direct comparison of ESMs by providing a suite of common drivers and standardized output formats (Taylor et al., 2011). Analysis of CMIP5 ESMs indicates that the negative feedback between land carbon and atmospheric $\mathrm{CO}_{2}$ concentration is larger than the positive feedback between land carbon and climate warming (Arora et al., 2013). Also, inter-model variation in atmospheric $\mathrm{CO}_{2}$ projections during the second half of the 21 st century correlates with biases that were present by 2005 (Hoffman et al., 2014). Observational data on the sensitivity of atmospheric $\mathrm{CO}_{2}$ growth rate to tropical temperature have been used to constrain the future climate response of tropical carbon stocks projected by CMIP4 ESMs (Cox et al., 2013). Finally, the IPCC 5th assessment report (Ciais et al., 2013) shows that land carbon storage is the largest source of uncertainty in future carbon cycle projections, and this uncertainty has not changed since CMIP4 (Friedlingstein et al., 2006).

Previous work has shown that within and between ESMs, variations in contemporary SOC stocks are mostly driven by model estimates of NPP, parameterization of the intrinsic decomposition rate (fitted at $15^{\circ} \mathrm{C}$ and optimal soil moisture), and the temperature dependency of heterotrophic respiration (Todd-Brown et al., 2013). In high northern latitudes, soil carbon stocks from CMIP5 ESMs deviate substantially from observations mainly because ESMs do not directly represent permafrost carbon (Koven et al., 2011, 2013b; ToddBrown et al., 2013). Surprisingly, soil moisture variations have very little effect on contemporary SOC stocks in most CMIP5 models (Todd-Brown et al., 2013), in contrast to experimental studies (Cook and Orchard, 2008) and previous work carried out with individual models (Exbrayat et al., 2013; Falloon et al., 2011; Ise and Moorcroft, 2006). Overall, ESMs perform poorly when global soil carbon distributions are compared to benchmark data sets, calling into question their ability to simulate future changes in SOC (Todd-Brown et al., 2013). However, to date no studies have analyzed patterns and drivers in ESM-simulated SOC change over the 21 st century.

Because of the potential importance of SOC for future carbon-climate feedbacks, the goal of our current study was to evaluate ESM estimates of global SOC changes during the 21st century from ESM simulations contributed to CMIP5. Specifically, we aimed to (1) compare SOC changes over the 21 st century across ESMs, (2) identify the drivers of SOC change within and between ESMs, and (3) assess the reliability of ESM projections by evaluating these drivers and SOC changes in the context of global data sets and empirical findings available from global change studies. Our analyses were 
conducted with the historical and RCP 8.5 future scenarios, where RCP 8.5 assumes "business as usual" greenhouse gas emissions leading to $\mathrm{CO}_{2}$ concentrations of $935 \mathrm{ppm}$ by 2100 (Riahi et al., 2007).

\section{Methods}

\subsection{Earth system models}

Outputs from ESMs that contributed to CMIP5 (Taylor et al., 2011) were downloaded from the Earth System Grid Federation repository. The terrestrial decomposition sub-models of these ESMs all use systems of first-order linear ordinary differential equations with 1-9 substrate pools. The decomposition and transfer rates of the substrate pools have temperature sensitivities that are either $Q_{10}$, Arrhenius, increase to an optimal point and then decrease, or some linear approximation of these functions. In response to soil moisture, decomposition rates either increase monotonically or increase to an optimal point and then decrease (Table S1, extended from Todd-Brown et al., 2013).

Results from the historical and RCP 8.5 experiments (Taylor et al., 2011) were analyzed. The historical simulations were forced with observation-based estimates of $\mathrm{CO}_{2}$ and other greenhouse gas mixing ratios, aerosol emissions, and land use change scenarios, where appropriate, from 18502005. Some models also incorporated natural variability through specified changes in solar radiation and volcanic activity. All models started at 1850, except for GFDL-ESM2G and HadGEM2-ES, which began at 1861 and 1860, respectively. The RCP 8.5 is a high radiative forcing scenario with a prescribed atmospheric $\mathrm{CO}_{2}$ mole fraction ranging from 378 to $935 \mathrm{ppm}$ for the period 2006-2100. The outputs from the historical and RCP 8.5 experiments were merged to create a continuous record from 1850 to 2100 (Table S1). We chose to use model runs with prescribed $\mathrm{CO}_{2}$ concentrations, as opposed to emissions-driven experiments, for consistent comparison of the strength of the $\mathrm{CO}_{2}$ fertilization effects across models and to avoid changes in projected temperature and climate variability due to different $\mathrm{CO}_{2}$ concentrations in the models.

We used annual, globally gridded SOC, litter, coarse woody debris carbon, soil temperature, total soil water, heterotrophic respiration, and NPP in our analysis (cSoil, cLitter, cCwd, tsl, mrso, rh, and npp, respectively, from the CMIP5 variable list). The reported monthly values for each model were averaged to create annual gridded means. Not all ESMs reported litter or coarse woody debris carbon; thus soil, litter, and coarse woody debris carbon variables were summed and are referred to as "soil organic carbon" (SOC) throughout this analysis. If multiple ensembles were reported for an individual model, then the ensembles were averaged. Global totals and means were constructed using the land cell area and the land surface fraction (areacella and sftlf, respec- tively). Soil temperature used in this analysis was calculated as the depth-weighted average from the top $10 \mathrm{~cm}$. Soil water for each model was expressed as a gridded fractional soil water content, calculated from the total soil water content, and divided by the maximal grid soil water content in the first 10 years of the historical run. In general, ESMs did not maintain soil carbon balance with the carbon flux variables described above (additional carbon fluxes that consume or diverted NPP in some ESMs included grazing, harvest, land use change, and fire); thus we computed annual soil inputs for each model as the annual change in SOC $(\Delta C)$ plus the carbon lost due to heterotrophic respiration $(R)$ summed for each year, that is, $I=\Delta C+R$. Soil turnover times (inverse of the decomposition rates) were calculated annually from gridded and global totals of SOC stocks and heterotrophic respiration. Soil carbon fluxes were calculated from the gridded and global annual differences in SOC stocks.

Many modeling centers submitted multiple ESMs to the CMIP5 repository. In these cases, one model was selected from each model center for analysis. If a model was recommended by the modeling center, that model was used. Otherwise, the model with the highest grid resolution was used. Finally, if no model was preferred by the modeling center and the models were of equal resolution, then a model was randomly selected.

We selected one ESM per modeling center because there were high correlations in the spatial distribution of 21 st century SOC change across models within modeling centers. In general, the spatial patterns of SOC change during the 21 st century in models from the same center were more similar than the spatial patterns from different modeling centers (Fig. S1), similar to previous results with spatial patterns in modern SOC (Todd-Brown et al., 2013). Thus model outputs from the same center are non-independent, which could inflate the significance of statistical tests (e.g., regressions) applied to multiple models. In some cases, models from different centers also produced highly correlated predictions because they used the same land carbon sub-model (e.g., CESM1(BGC), and NorESM1-ME). In these cases, we still included one model from each center so as not to exclude other factors that might differ across modeling centers, including ocean and atmospheric components of the ESMs that influence precipitation and land surface temperatures. We emphasize that these model predictions are not completely independent and that statistical tests based on them should be interpreted with caution.

\subsection{Biome definitions}

We conducted biome-level analyses by constructing a common biome mask (similar to Todd-Brown et al. (2013)). We downloaded vegetation type classifications for the period 2001-2009 from the MODIS satellite mission to construct the biome map (Friedl et al., 2010; NASA Land Processes Distributed Active Archive Center (LP DAAC), 2008). The 
vegetative area coverage was regridded from the $0.05 \times 0.05$ MODIS grid to each individual ESM grid cell using an areaweighted scheme. The maximal vegetation type for an individual grid cell was then used to assign a biome.

\subsection{Contribution of inputs and outputs to SOC change}

We used two techniques to separate the relative contributions of changes in carbon inputs and outputs to the total change in SOC over time. For the first technique, we constructed two possible temporal scenarios for gridded SOC stock evolution to illustrate the relative impact of changes in inputs versus decomposition rate on SOC. In the "constant decomposition rate" scenario, soil carbon inputs evolved as predicted by the model but the SOC decomposition rate was held constant at the 1850 value. In the "constant soil inputs" scenario, decomposition rate evolved as predicted by the model but soil carbon input was held constant at the 1850 value. This is the only analysis that used the entire $1850-2100$ period. We examined this interval to check for consistency in ecosystem responses over the historical and forecasted time periods.

For the second technique, we modeled ESM change in soil carbon over the 21 st century as a function of the change in soil inputs and decomposition rate. First we assumed that the change in soil carbon is proportional to the change in steadystate soil carbon expected for soil inputs and decomposition occurring at the start and end of the 21st century:

$C_{\text {end }}-C_{\text {start }}=\frac{I_{\text {end }}}{k_{\text {end }}}-\frac{I_{\text {start }}}{k_{\text {start }}}$,

where end and start are averaged over 2090-2099 and 19972006, respectively; $C$ is the global soil carbon stock; $I$ is the associated average soil carbon input; and $k$ is the decomposition rate calculated from global heterotrophic respiration and soil carbon stocks. We can rearrange this equation to generate the following:

$C_{\text {end }}-C_{\text {start }}=\left(\frac{1+\frac{\Delta I}{I_{\text {start }}}}{1+\frac{\Delta k}{k_{\text {start }}}}-1\right) C_{\text {start }}$.

Using regression analysis with the terms on the right-hand side of Eq. (2), we assessed the relative contributions of changes in soil inputs, changes in decomposition rate, and initial soil carbon stocks to changes in ESM soil carbon.

\subsection{Drivers of changes in heterotrophic respiration and decomposition rate}

To investigate the drivers of heterotrophic respiration change and decomposition, we used a reduced complexity model (Todd-Brown et al., 2013). This model assumes that the change in heterotrophic respiration is proportional to total SOC:

$R=k C$, where $R$ is the heterotrophic respiration, $k$ is the decomposition rate (inverse of the turnover time), and $C$ is the total SOC. We then evaluated drivers of the change in decomposition rate $(k)$ by assuming the decomposition rate is dependent on the intrinsic decomposition rate $(\kappa$, spatially and temporally constant) times the temperature dependency $\left(Q_{10}(T)\right)$ and soil moisture dependency ( $W$ raised to the power $b$ ) of decomposition for each model:

$k=\kappa Q_{10}^{\left(\frac{T-15}{10}\right)} W^{b}$,

where the temperature $(T)$ dependency function represents a $Q_{10}$-factor increase for each $10^{\circ} \mathrm{C}$ of warming from a $15^{\circ} \mathrm{C}$ baseline, and the moisture dependency function monotonically increases ( $b$ greater than 0 ) with respect to relative water content.

After substituting Eq. (4) into Eq. (3), we represented heterotrophic respiration as a function of SOC and the environmental drivers:

$R=\kappa Q_{10}^{\left(\frac{T-15}{10}\right)} W^{b} C$.

Equation (5) was then fitted to ESM variables as described below to generate ESM-specific $\kappa, Q_{10}$, and $b$ parameters.

We also used Eq. (4) to derive the change in decomposition rate by taking the first-order derivative as follows:

$\frac{\mathrm{d} k}{\mathrm{~d} t}=k\left\{\frac{\ln \left(Q_{10}\right)}{10} \frac{\mathrm{d} T}{\mathrm{~d} t}+\frac{b}{W} \frac{\mathrm{d} W}{\mathrm{~d} t}\right\}$.

We then assumed that the rate of change can be approximated by a single time step over the entire time period, giving the following simplification:

$\Delta k=k_{\text {start }}\left\{\ln \left(Q_{10}\right) \frac{\Delta T}{10}+b \frac{\Delta W}{W_{\text {start }}}\right\}$,

where $k_{\text {start }}$, and $W_{\text {start }}$ are the contemporary (1997-2006) 10 -year mean of decomposition rate (soil respiration divided by soil carbon) and relative soil water content, respectively; $\Delta k, \Delta W$, and $\Delta T$ are the changes from the contemporary (1997-2006) to the final (2090-2099) 10-year means of decomposition rate, soil water, and soil temperature. Note that Eq. (7) is independent of the inferred intrinsic decomposition rate $(\kappa)$. In our analyses we simplified Eq. (7) to include just the temperature term because soil water was not a significant term in the model. Gridded values were used for withinmodel comparisons. Global total SOC and heterotrophic respiration were used for between-model analyses with the decomposition rate calculated from the previously mentioned global totals. Area-weighted global mean soil temperature and soil water content were used for the between-model comparisons. 


\section{Parameterization}

The intrinsic decomposition rate $(\kappa)$ and environmental dependency parameters $\left(Q_{10}, b\right)$ in Eq. (5) were fitted using the ESM initial historical 10-year gridded mean (1850-1859 in most cases) of heterotrophic respiration, SOC, soil temperature, and soil moisture. The parameters were fitted using a constrained Broyden-Fletcher-Goldfarb-Shanno optimization algorithm, a quasi-Newtonian method, as implemented in R 2.13.1 (R Development Core Team, 2012). This algorithm was selected for parameter fitting because of its robust convergence and short run time. The following variable ranges were considered in the parameterization: $k \epsilon\left(10^{-4}, 10\right), Q_{10} \in(1,4)$, and $b \in(0,3)$.

\subsection{Benchmark constraints}

Two modern benchmark constraints were used to select models that best represent the modern carbon cycle with the expectation that the best models would simulate a narrower range of soil carbon change over the 21st century. Modern global soil carbon stocks were constrained using estimates from the Harmonized World Soil Database (FAO/IIASA/ISRIC/ISSCAS/JRC, 2012) with qualitative uncertainties (Todd-Brown et al., 2013). Modern global NPP estimates were taken from Ito (2011).

\section{Results}

Over the 21st century, ESMs predicted SOC changes ranging from a $253 \mathrm{Pg} \mathrm{C}$ gain (HadGEM2-ES) to a $72 \mathrm{Pg} \mathrm{C}$ loss (MIROC-ESM) with a multi-model mean gain of $65 \mathrm{PgC}$ (Fig. 1, Tables 1 and 2). Five models (HadGEM2-ES, MPIESM-MR, BCC-CSM1.1(m), BNU-ESM, and INM-CM4) estimated SOC gains greater than $75 \mathrm{Pg}$ C. Four other models (IPSL-CM5A-MR, GFDL-ESM2G, CESM1(BGC), and NorESM1-ME) predicted moderate changes in SOC ranging from a $15 \mathrm{PgC}$ gain to a $16 \mathrm{PgC}$ loss. Two models (CanESM2 and MIROC-ESM) projected an SOC loss of more than $50 \mathrm{PgC}$. In many cases, large absolute changes in SOC also translated into large relative changes, including a $23 \%$ gain by HadGEM2-ES, a $22 \%$ gain by BCCCSM1.1(m), and a $14 \%$ gain by BNU-ESM (Fig. 1, Table 2).

For four of the five models with the highest gains (more than 75 Pg C: HadGEM2-ES, MPI-ESM-MR, BNU-ESM, and INM-CM4), most of the global SOC gain was located in boreal and tundra biomes; BCC-CSM1.1(m) was an exception, showing roughly equal gains in high northern latitude and other biomes (Fig. 2, Table 1). In contrast, the two models showing the greatest losses in SOC (more than $50 \mathrm{Pg} \mathrm{C}$ : MIROC-ESM and CanESM2) showed most of those losses in the tropical forest and grassland and savanna biomes (Table 1). Three of the four models with moderate SOC changes showed more SOC change in other biomes than in high northern latitude biomes; GFDL-ESM2G was an exception and showed a $37 \mathrm{PgC}$ loss in the northern latitudes balanced by a $41 \mathrm{PgC}$ gain in the other latitudes (Table 1). These diverging patterns were also apparent in maps of SOC change (Figs. 2 and 3) and tended to follow the distribution of SOC at the beginning of the analysis period (Fig. S2).

SOC change was not well constrained by modern SOC and NPP benchmarks (Fig. 4). Although 5 of the 11 models met modern SOC benchmarks, SOC change predicted by these models ranged from a $51 \mathrm{Pg} \mathrm{C}$ loss (CanESM2) to a $203 \mathrm{Pg} \mathrm{C}$ gain (BCC-CSM1.1(m)). Further constraining models based on modern SOC and NPP global totals reduced the number of models considered from five to two; however, the range of SOC change remained the same.

\subsection{Changes in NPP, soil inputs, respiration, and turnover times}

All of the models had increases in NPP and thus soil inputs during the 21st century (Table 2, Fig. 1). NPP increases occurred across the globe in most models, with absolute changes ranging from $5 \mathrm{PgC}^{-1}$ (NorESM1-ME)

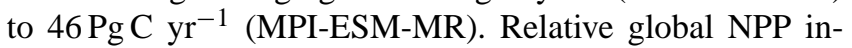
creases varied between $11 \%$ (NorESM1-ME) and 59\% (HadGEM2-ES) (Table 2). NPP increases generally followed contemporary distributions (Figs. S3, S4, S5); however, decreases in NPP were notable in the Amazon Basin in three models (BCC-CSM1.1(m), HadGEM2-ES, and CanESM2) and southern sections of North America, southern Africa, and southwest South America in IPSL-CM5A-MR (Figs. S4, S5). For most models, global SOC input for the period 19972006 and 2090-2099 matched the respective mean annual NPP relatively closely, with global differences of less than $7 \mathrm{Pg} \mathrm{C} \mathrm{yr}^{-1}$ (approximately $15 \%$ of NPP) over the 21 st century (Table 2). However, there were more substantial differences of $13-36 \mathrm{PgC}^{-1}$ between NPP and soil inputs in three models (IPSL-CM5A-MR, GFDL-ESM2G, MPIESM-MR). These differences could be due to either accumulation of carbon in vegetation (and thus time delays in the delivery of this carbon to SOC pools) or losses through other pathways such as land use change, harvesting, or fire.

Global heterotrophic respiration also increased in all models, with absolute increases ranging from $7 \mathrm{Pg} \mathrm{C} \mathrm{yr}^{-1}$ (CESM1(BGC), NorESM1-ME) to $43 \mathrm{Pg} \mathrm{C} \mathrm{yr}^{-1}$ (HadGEM2-ES) (Table 2). These increases in heterotrophic respiration were caused by the increase in soil inputs described above and, simultaneously, decreases in global turnover times between 12 years (25\%; MIROC-ESM) and 2.1 years (15\%; CESM1(BGC)) (Fig. 1, turnover calculated by dividing global soil carbon by global heterotrophic respiration). In many ESMs, gridded turnover times decreased by 100 years or more in high northern latitudes (Figs. S6, S7). For comparison, contemporary heterotrophic respiration fluxes ranged from $43 \mathrm{Pg} \mathrm{C} \mathrm{yr}^{-1}$ (CESM1(BGC)) to $76 \mathrm{Pg} \mathrm{Cyr}^{-1}$ (MPI-ESM-MR) and global turnover times ranged from 13 years (CESM1(BGC)) to 46 years 
Contemporary 21st century absolute change 21st century relative change
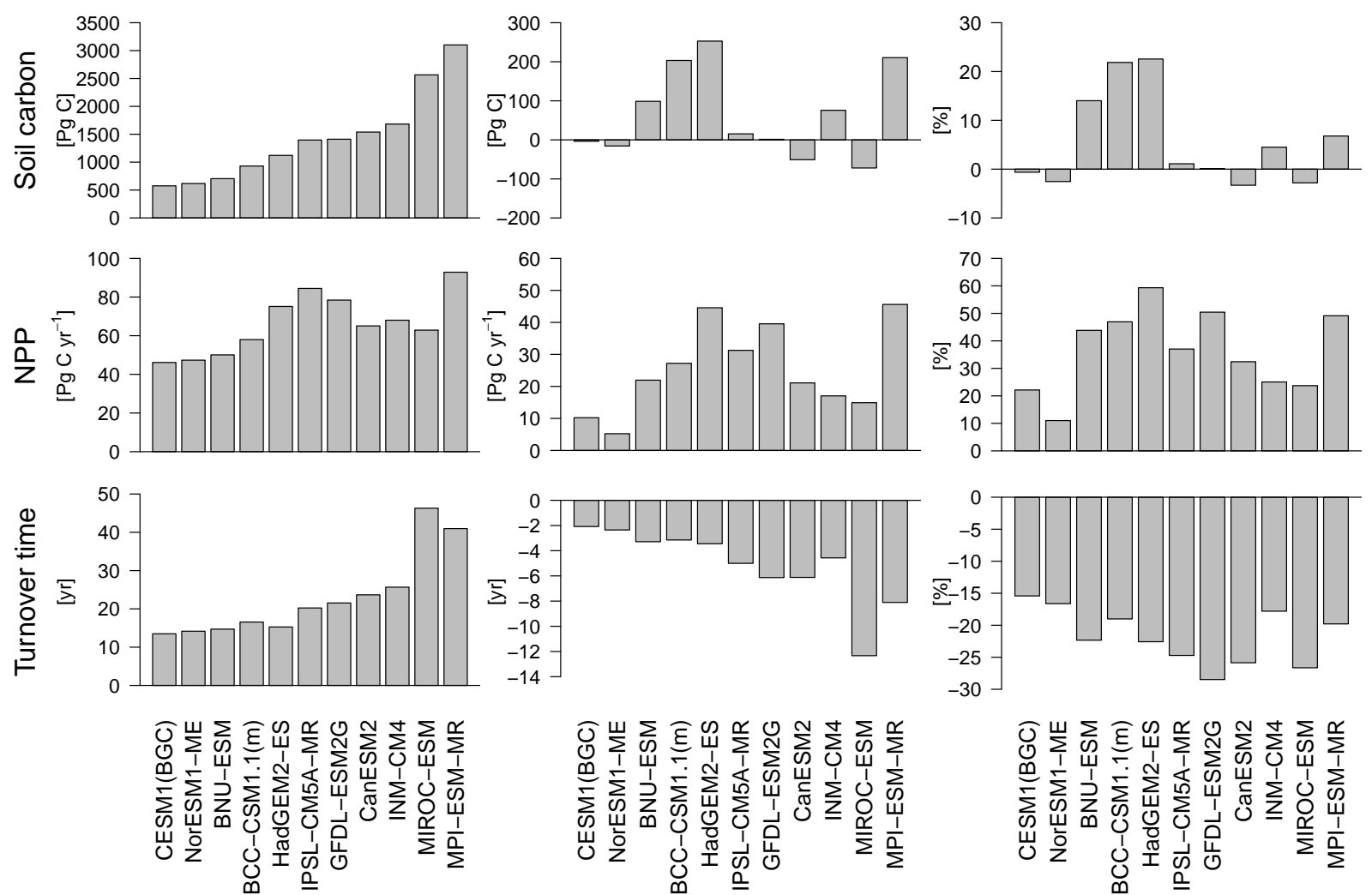

Fig. 1. Contemporary values, absolute changes, and relative changes of soil carbon, net primary production (NPP), and turnover times for CMIP5 Earth system models. Contemporary values of soil carbon, NPP, and turnover times are reported for the 1997-2006 mean using model output from the historical experiment. Changes for the 21st century were estimated from the difference between 2090-2099 and 1997-2006 mean model estimates from the RCP 8.5 experiment. Turnover times were calculated from global soil carbon stocks divided by global heterotrophic respiration.

(MIROC-ESM) (Fig. 1, Table 2, and starting distributions in Fig. S8).

\subsection{Changes in net SOC flux}

By the end of the 21st century, the net SOC flux was negative (carbon being lost from the soil) in most models, ranging between $-0.2 \mathrm{PgC} \mathrm{yr}^{-1}$ (BNU-ESM and CESM1(BGC)) and $-3.0 \mathrm{PgC} \mathrm{yr}^{-1}$ (MIROC-ESM), with the exceptions of HadGEM1-ES $\left(+3.0 \mathrm{Pg} \mathrm{C} \mathrm{yr}^{-1}\right)$, BCC-CSM1(m) $\left(+2.1 \mathrm{Pg} \mathrm{C} \mathrm{yr}^{-1}\right)$, and MPI-ESM-MR $\left(+1.4 \mathrm{PgC} \mathrm{yr}^{-1}\right)$. Modern net SOC flux had a much smaller range, between $-0.5 \mathrm{Pg} \mathrm{Cyr}^{-1}$ (CanESM2) and $+1.9 \mathrm{PgC} \mathrm{yr}^{-1}$ (MIROCESM) with a multi-model mean of $+0.7 \mathrm{Pg} \mathrm{C} \mathrm{yr}^{-1}$. The SOC in six models switched from neutral or net sinks to net sources of carbon (Table 2).

\subsection{Changes in soil temperature and soil moisture}

Predicted changes in soil temperature and moisture varied widely across models, with consequences for SOC dynam- ics. Across all models there was a warming trend over the 21 st century in soil temperature (Table 2), with a multi-model mean increase of $4.8^{\circ} \mathrm{C}$ and a range between $3.1^{\circ} \mathrm{C}$ (INMCM4) and $6.4^{\circ} \mathrm{C}$ (HadGEM1-ES). Warming was most intense in the high northern latitudes in most models (Fig. S9), ranging between $3.1^{\circ} \mathrm{C}$ (INM-CM4, BCC-CSM1.1(m)) and $8.0^{\circ} \mathrm{C}$ (MIROC-ESM) when averaged across boreal and arctic tundra biomes (Table S2). In most models, soil temperatures increased in these biomes by a smaller amount than surface air temperatures because loss of snow cover increased winter heat fluxes to the atmosphere. Koven et al. (2013a) show the importance of correctly simulating the relationship between air and soil temperatures in this region.

The change in fractional soil water content over the entire soil column of each model was even more variable across models over the 21 st century, with some of the models becoming drier and others becoming wetter (Table 2, Fig. S10) compared to starting distributions shown in Fig. S11. However, the magnitude of change in global mean soil water was relatively small, ranging from -0.046 
Table 1. Change in soil carbon (Pg C) between 1997-2006 and 2090-2099 biome means; the change in the high northern latitude biomes (tundra and boreal forests); the change in other biomes (tropical rainforest, temperate forest, desert and scrubland, grasslands and savanna, and cropland and urban); and the change in global soil carbon stock across all ESMs. Multi-model means and standard deviations are given in the last two columns.

\begin{tabular}{|c|c|c|c|c|c|c|c|c|c|c|c|c|c|}
\hline & 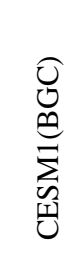 & 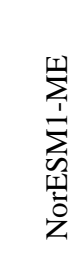 & 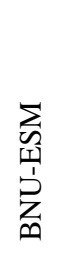 & 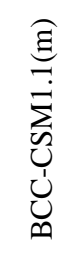 & 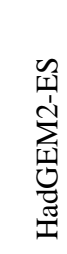 & 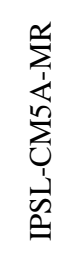 & 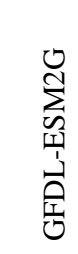 & 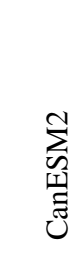 & $\sum_{\sum_{Z}^{1}}^{+}$ & 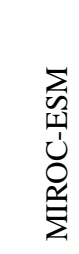 & $\begin{array}{l}\sum_{1}^{\alpha} \\
\sum_{n=1}^{1} \\
\frac{1}{1} \\
\frac{1}{\Sigma}\end{array}$ & 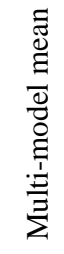 & 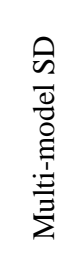 \\
\hline Tundra & 3 & 3 & 54 & 50 & 85 & 2 & -9 & 3 & 24 & 1 & 64 & 26 & 32 \\
\hline Boreal forest & -1 & -3 & 18 & 47 & 61 & -5 & -28 & -6 & 22 & -22 & 62 & 13 & 32 \\
\hline Tropical rainforest & -11 & -15 & 4 & 14 & 5 & 14 & 6 & -15 & 9 & -34 & 9 & -1 & 15 \\
\hline Temperate forest & -2 & -4 & 0 & 7 & 11 & 0 & 2 & -1 & 0 & -5 & 6 & 1 & 5 \\
\hline Desert and shrubland & 2 & 2 & 11 & 16 & 16 & 2 & 13 & -3 & 4 & 14 & 69 & 13 & 20 \\
\hline Grasslands and savanna & 1 & 0 & 8 & 37 & 36 & 3 & 7 & -20 & 10 & 3 & -10 & 7 & 17 \\
\hline Cropland and urban & 4 & 2 & 2 & 32 & 34 & -2 & 13 & -9 & 6 & -31 & 7 & 5 & 18 \\
\hline Permanent wetlands & 0 & 0 & 0 & 0 & 2 & 0 & -2 & 0 & 0 & -2 & 3 & 0 & 1 \\
\hline Snow and ice & 0 & 0 & 2 & 0 & 3 & 0 & 0 & 0 & 0 & 4 & 1 & 1 & 1 \\
\hline High northern latitude & 2 & 0 & 72 & 97 & 146 & -2 & -37 & -3 & 46 & -21 & 126 & 39 & 63 \\
\hline Other & -6 & -16 & 25 & 106 & 102 & 18 & 41 & -48 & 29 & -53 & 81 & 25 & 55 \\
\hline Total & -4 & -16 & 99 & 203 & 253 & 15 & 1 & -51 & 76 & -72 & 211 & 65 & 113 \\
\hline
\end{tabular}

to $0.007\left(\mathrm{~kg}\right.$-water $\mathrm{m}^{2} \mathrm{~kg}^{-1}$ max. water $\left.\mathrm{m}^{-2}\right)$ across the $21 \mathrm{st}$ century (Table 2 ).

\subsection{Drivers of SOC change}

Changes in global SOC were the net effect of large increases in inputs and large decreases in turnover times (Fig. 5). For all ESMs, most of the change in SOC inputs and turnover is projected to occur in the 21 st century, not over the historical period (1850-2006). In the constant turnover time scenario (Fig. 5, green dashed lines), between 160 (NorESM1ME) and 1230 (MPI-ESM-MR) Pg C of SOC accumulated from 1850 to 2100 across models due to increases in SOC inputs associated with increased NPP. Conversely, in the constant carbon input scenario (Fig. 5, red dotted lines), between 104 (MIROC-ESM) and 629 (MPI-ESM-MR) Pg C were lost from global soil stocks as soils warmed and heterotrophic respiration increased. For all models, the amount of carbon potentially gained due to increasing inputs over time was greater than the amount of carbon potentially lost through increases in decomposition rates.

Between ESMs, the change in global SOC was significantly explained by Eq. (2) using the relative changes in soil inputs and decomposition rates, and the size of the initial SOC pool $\left(R^{2}=0.89, p<0.01\right.$, Fig. 6a). With all models included, the regression slope was 0.73 , but it approached 1.0 when MIROC-ESM was removed. Explanatory power was similarly high when SOC change was expressed proportionally to the change in steady state (Eq. $1 ; R^{2}=0.88, p<0.01$, Fig. S12a) or relative change in the inputs and decomposi- tion rate $\left(R^{2}=0.83, p<0.01\right.$, Fig. S12b). The total change in global SOC was not significantly correlated with the initial SOC $\left(R^{2}=0.00, p=0.86\right.$, Fig. $\left.6 \mathrm{~b}\right)$, nor the change decomposition rate $\left(R^{2}=0.08, p=0.39\right.$, Fig. $\left.6 \mathrm{c}\right)$. Instead, much of this change was attributed to the change in soil inputs $\left(R^{2}=0.54, p<0.01\right.$, Fig. $\left.6 \mathrm{~d}\right)$, with the remaining variation due to the interaction between initial SOC, changes in soil inputs, and changes in decomposition rate.

Within ESMs, changes in SOC at each grid cell over the 21 st century were not always consistent with Eq. (2). Explanatory power was good for three models $\left(0.88>R^{2}>\right.$ $0.78, p<0.05)$, moderate for five models $\left(0.50>R^{2}>\right.$ $0.19, p<0.05)$, and not significant for three models. Neither the change in soil inputs nor the change in decomposition rate alone explained more than $20 \%$ of the variation in SOC changes within ESMs (Table S3).

\subsection{Drivers of change in decomposition between models}

Between-model variation in the change in global mean decomposition rate was well explained by model parameterization and environmental variables (Fig. 7). Together, the initial decomposition rate, the temperature-dependency parameter $\left(Q_{10}\right)$ of each ESM, and the ESM-simulated change in soil temperature explained most of the variation between ESMs as modeled by Eq. (7) $\left(R^{2}=0.80, p<0.01\right.$, Fig. 7a). The change in decomposition rate was moderately explained by the initial decomposition rate $\left(R^{2}=0.49, p=0.02\right.$, Fig. $\left.7 \mathrm{~b}\right)$. Other individual terms in Eq. (7), including variation in $Q_{10}$ and ESM-simulated change in soil temperature, did not 
Table 2. Starting value (1997-2006 mean), final value (2090-2099 mean), absolute change, and relative change of soil carbon, net primary productivity (NPP), soil inputs, heterotrophic respiration, net SOC flux (positive values are carbon gains by the SOC pool, negative values are carbon losses), area-weighted soil temperature, and area-weighted normalized soil water content. Soil water is mean gridded soil water content divided by the grid maximum soil water content at the 10 -year initial historical mean value.

\begin{tabular}{|c|c|c|c|c|c|c|c|c|c|c|c|c|c|c|}
\hline & & 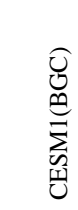 & 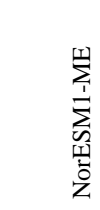 & 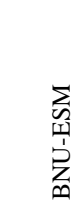 & 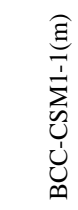 & 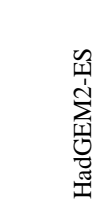 & $\begin{array}{l}\sum_{i=1}^{\infty} \\
\sum_{\substack{n \\
n}}^{n} \\
\stackrel{n}{=}\end{array}$ & 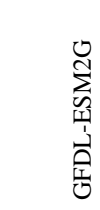 & 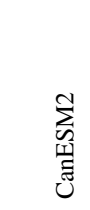 & $\sum_{i}^{+}$ & 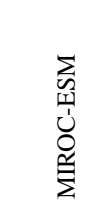 & 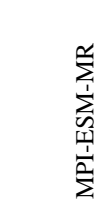 & 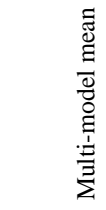 & 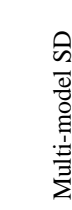 \\
\hline \multirow{2}{*}{$\begin{array}{l}\text { SOC } \\
(\mathrm{Pg} \mathrm{C})\end{array}$} & 2006 & 575 & 617 & 704 & 930 & 1121 & 1396 & 1411 & 1539 & 1683 & 2565 & 3101 & 1422 & 801 \\
\hline & 2099 & 571 & 601 & 803 & 1134 & 1374 & 1412 & 1412 & 1488 & 1759 & 2493 & 3312 & 1487 & 816 \\
\hline \multirow{4}{*}{$\begin{array}{l}\mathrm{NPP} \\
\left(\mathrm{PgC} \mathrm{yr}^{-1}\right)\end{array}$} & 2006 & 46 & 47 & 50 & 58 & 75 & 84 & 78 & 65 & 68 & 63 & 93 & 66 & 15 \\
\hline & 2099 & 56 & 53 & 72 & 85 & 120 & 116 & 118 & 86 & 85 & 78 & 138 & 92 & 28 \\
\hline & Abs. Change & 10 & 5 & 22 & 27 & 45 & 31 & 40 & 21 & 17 & 15 & 46 & 25 & 14 \\
\hline & Rel. Change (\%) & 22.1 & 11.0 & 43.8 & 46.9 & 59.3 & 37.0 & 50.4 & 32.4 & 25.1 & 23.7 & 49.1 & 36.5 & 14.8 \\
\hline \multirow{2}{*}{$\begin{array}{l}\text { SOC inputs } \\
\left(\mathrm{Pg} \mathrm{C} \mathrm{yr}^{-1}\right)\end{array}$} & 2006 & 43 & 44 & 49 & 57 & 75 & 69 & 65 & 65 & 67 & 57 & 77 & 61 & 12 \\
\hline & 2099 & 50 & 51 & 70 & 87 & 119 & 92 & 91 & 84 & 83 & 70 & 102 & 82 & 21 \\
\hline \multirow{2}{*}{$\begin{array}{l}\text { Heterotrophic } \\
\text { respiration } \\
\left(\mathrm{Pg} \mathrm{C} \mathrm{yr}^{-1}\right)\end{array}$} & Abs. Change & 7 & 7 & 22 & 28 & 43 & 24 & 26 & 20 & 18 & 18 & 25 & 22 & 10 \\
\hline & Rel. Change (\%) & 17.5 & 16.9 & 46.8 & 50.5 & 58.3 & 34.3 & 40.0 & 30.4 & 27.1 & 32.5 & 33.1 & 35.2 & 12.9 \\
\hline \multirow{3}{*}{$\begin{array}{l}\text { Net SOC flux } \\
\left(\mathrm{Pg} \mathrm{C} \mathrm{yr}^{-1}\right)\end{array}$} & 2006 & 0.0 & 0.3 & 0.8 & 0.9 & 1.4 & 0.5 & -0.4 & -0.5 & 1.0 & 1.9 & 1.5 & 0.7 & 0.8 \\
\hline & 2099 & -0.2 & -0.4 & -0.2 & 2.1 & 3.0 & -0.4 & -0.6 & -0.7 & -0.4 & -3.0 & 1.4 & 0.0 & 1.6 \\
\hline & Abs. Change & -0.2 & -0.7 & -1.0 & 1.2 & 1.6 & -0.9 & -0.3 & -0.2 & -1.3 & -4.9 & -0.1 & -0.6 & 1.7 \\
\hline \multirow{3}{*}{$\begin{array}{l}\text { Soil } \\
\text { temperature } \\
\left({ }^{\circ} \mathrm{C}\right)\end{array}$} & 2006 & 16.4 & 14.4 & 17.2 & 17.2 & 14.8 & 14.2 & 14.0 & 15.7 & 11.1 & 16.4 & 14.6 & 15.1 & 1.8 \\
\hline & 2099 & 20.2 & 18.5 & 21.5 & 20.9 & 21.3 & 20.3 & 17.8 & 21.8 & 14.2 & 22.6 & 19.7 & 19.9 & 2.4 \\
\hline & Abs. Change & 3.8 & 4.2 & 4.3 & 3.8 & 6.4 & 6.1 & 3.8 & 6.1 & 3.1 & 6.2 & 5.1 & 4.8 & 1.2 \\
\hline \multirow{3}{*}{$\begin{array}{l}\text { Soil water } \\
\left(\mathrm{kg} \mathrm{m}^{2} \text { water }\right. \\
\mathrm{kg}^{-1} \mathrm{~m}^{-2} \\
\text { max. water })\end{array}$} & 2006 & 0.249 & 0.035 & 0.261 & 0.189 & 0.498 & 0.675 & 0.560 & 0.119 & 0.354 & 0.651 & 0.311 & 0.355 & 0.215 \\
\hline & 2099 & 0.253 & 0.030 & 0.263 & 0.195 & 0.468 & 0.629 & 0.553 & 0.121 & 0.353 & 0.651 & 0.310 & 0.348 & 0.205 \\
\hline & Abs. Change & 0.004 & -0.005 & 0.002 & 0.007 & -0.030 & -0.046 & -0.007 & 0.002 & -0.001 & 0.001 & -0.001 & -0.007 & 0.016 \\
\hline
\end{tabular}

explain any significant variation (Fig. 7c and d), nor did the moisture term add any explanatory value.

\section{Discussion}

A key determinant of future climate-carbon cycle feedbacks is whether increased inputs from NPP (Matthews et al., 2005) or increased losses due to heterotrophic respiration (Davidson and Janssens, 2006) will dominate SOC responses to global change. Our analysis shows that increases in both NPP and heterotrophic respiration are large and relatively consistent across ESMs. What varies substantially is the difference between these two large fluxes under future conditions. Even though all ESMs simulate 15 to $28 \%$ declines in global SOC turnover times (Fig. 1), many models (7 of 11) simulate increases in global SOC over the 21st century. In these ESMs, increased NPP more than offsets increased SOC decomposition. A major challenge moving forward will be to constrain the uncertainty on these large fluxes enough to reliably esti- mate the net change in SOC over time. This challenge also applies to ESM vegetation pools where uncertainties in carbon turnover rates contribute to variation in vegetation carbon change across models (Friend et al., 2013).

\subsection{SOC decomposition in ESMs}

Given the importance of decomposition fluxes for SOC balance, we analyzed the factors underlying variation in decomposition changes across ESMs. Cross-model differences in decomposition change over the 21 st century mainly depend on the initial decomposition rate, temperature dependency of decomposition, and the temperature change predicted by the models (Fig. 7). Although these factors varied substantially across ESMs, the range of variation is broadly consistent with empirical observations. The intrinsic decomposition rate $\left(\kappa\right.$; fitted at $15^{\circ} \mathrm{C}$ and optimal soil moisture) varied between 6 and 24 years (Table S4), a range consistent with the parameterization of traditional biogeochemical models (e.g., Parton et al., 1993). $Q_{10}$ factors ranged between 1.4 and 

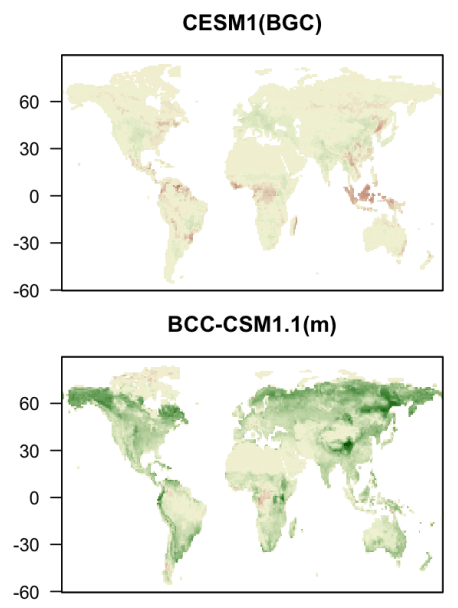

GFDL-ESM2G
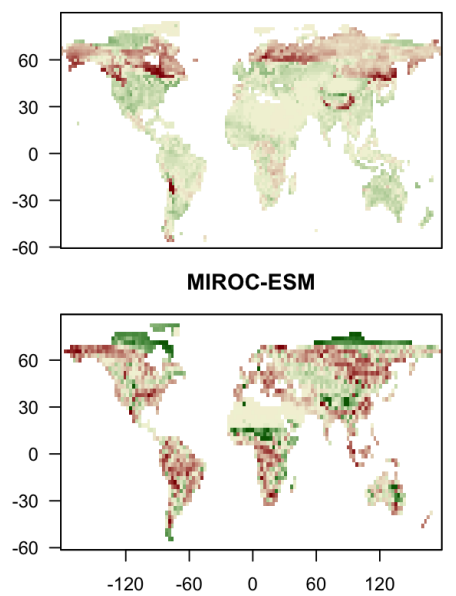

NorESM1-ME

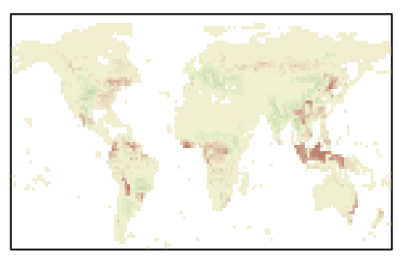

HadGEM2-ES

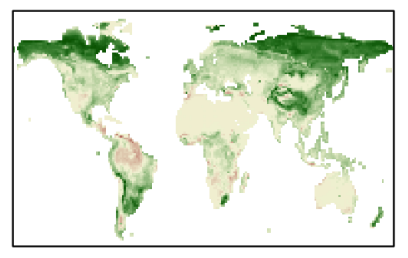

CanESM2
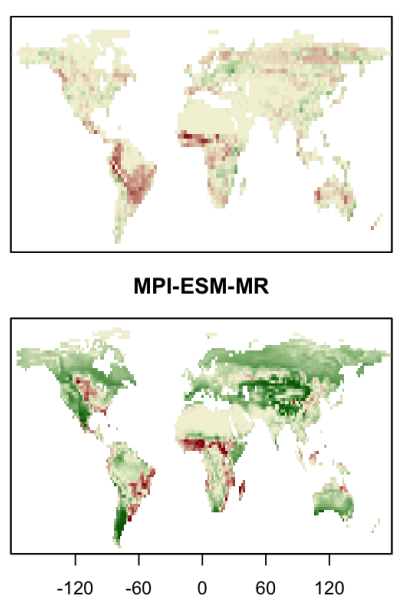

BNU-ESM

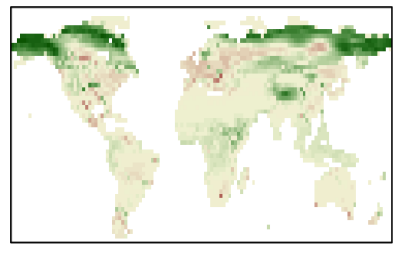

IPSL-CM5A-MR

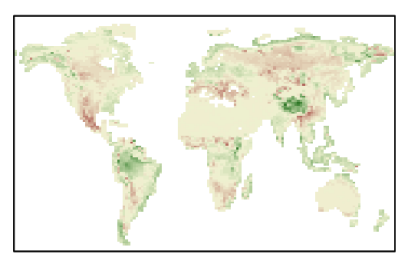

INM-CM4

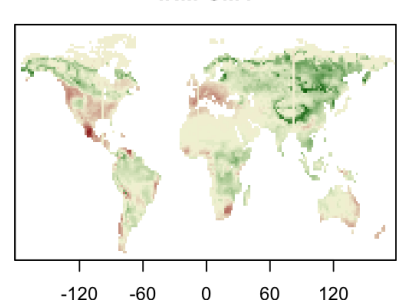

$\begin{array}{lllll}-120 & -60 & 0 & 60 & 120\end{array}$

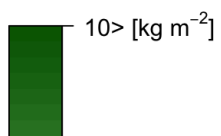

$-5$

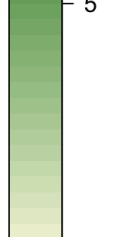

$-0$

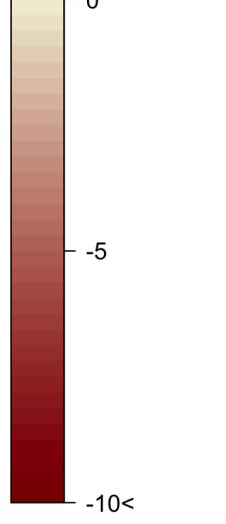

Fig. 2. Absolute change in soil carbon density $\left(\mathrm{kg} \mathrm{m}^{-2}\right)$ over the 21 st century for all models (difference in 10-year means; 2090-2099 minus 1997-2006).

2.2 (Table S4), consistent with the observed distribution of $Q_{10}$ values reported in the literature (Davidson and Janssens, 2006; Fierer et al., 2006; Mahecha et al., 2010). Modeled temperature changes in the ESMs, especially in northern latitudes (Koven et al., 2013a), are an additional source of uncertainty that should be addressed in future studies (Knutti and Sedláček, 2012).

Moisture dependency did not provide any additional explanation of variation in decomposition rate changes across ESMs nor did it substantially improve reduced complexity models of heterotrophic respiration within ESMs (Table S4), suggesting that it is not a primary driver of SOC decomposition change at the global scale. This result contrasts with previous work showing that individual global climate models are sensitive to moisture function selection (Exbrayat et al., 2013). Our analysis suggests that if ESMs are sensitive to moisture functions, that dependency can be captured by shifts in the intrinsic decomposition rate $(\kappa)$ or $Q_{10}$ parameter. However, it is also likely that climate change will result in small-scale variations in soil moisture that cancel out in global-scale analyses, thereby obscuring moisture effects on soil carbon.

\subsection{NPP and SOC inputs in ESMs}

All ESMs predicted substantial (11-59\%) increases in NPP over the 21st century (Table 2). These increases are primarily due to $\mathrm{CO}_{2}$ fertilization effects, and secondarily due to temperature and moisture change (Anav et al., 2013). Although plausible based on FACE studies (Norby et al., 2010; Piao et al., 2013), the increases in SOC inputs predicted by ESMs may not occur for several reasons. First, FACE studies have only been conducted in a limited number of ecosystems that are not representative of the entire terrestrial biosphere. FACE studies tend to be located in ecosystems with relatively high $\mathrm{CO}_{2}$ response, such as early- to mid-successional systems with high nutrient supply and rapidly growing vegetation (Körner, 2006; Norby and Zak, 2011). Ecosystems with closed nutrient cycles and full canopy development occupy the largest fraction of the global land surface, and current studies show a more limited $\mathrm{CO}_{2}$ fertilization response in 

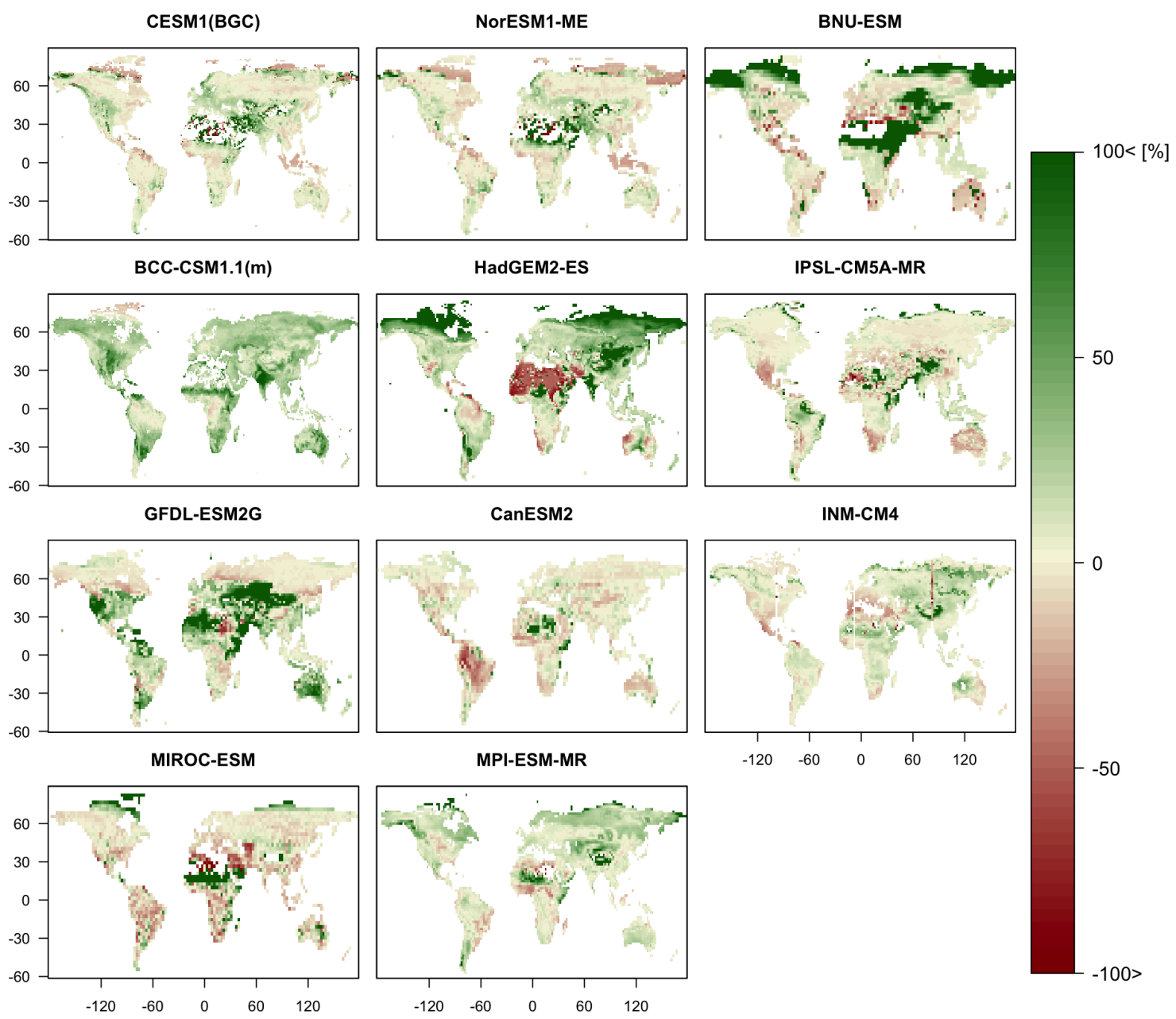

Fig. 3. Relative change in soil carbon density (\%) over the 21 st century for all models (difference in 10 -year means divided by modern soil carbon density; 2090-2099 minus 1997-2006 divided by 1997-2006).

these ecosystems (Bader et al., 2013). Second, nitrogen and phosphorus are expected to become progressively more limiting as biomass increases (Exbrayat et al., 2013), and nutrients could be lost from ecosystems that experience increases in precipitation and leaching.

On the other hand, some constraints on NPP could be alleviated by other aspects of global change. For example, increased nutrient mineralization under soil warming or increased nutrient inputs from atmospheric deposition could alleviate nutrient limitation (Bai et al., 2013; Rustad et al., 2001). An amplifying seasonal cycle of $\mathrm{CO}_{2}$ exchange in the Northern Hemisphere suggests that boreal and temperate forests are showing a stronger positive NPP response to contemporary environmental change than assumed in ESMs (Graven et al., 2013). However, some NPP constraints could also be exacerbated; for instance, reduced precipitation or increased evapotranspiration under climate change could lead to increased moisture limitation of plant growth.
Even if the terrestrial biosphere does respond to elevated $\mathrm{CO}_{2}$ in line with FACE studies, it is unclear how long this response can be maintained. In ESMs, the majority of predicted change in NPP and SOC inputs occurs beyond $550 \mathrm{ppm}$ $\mathrm{CO}_{2}$, a range unexplored in field studies. Additionally, FACE studies examine an unrealistic instantaneous change in $\mathrm{CO}_{2}$ rather than the relatively gradual $\mathrm{CO}_{2}$ change simulated in ESMs. The constant turnover time scenarios in Fig. 5 suggest that NPP sensitivity to global change (including $\mathrm{CO}_{2}$ change) is sustained throughout the 21st century in ESMs, well beyond the conditions simulated by most field experiments. Although a sustained response cannot be ruled out based on current experimental evidence, many photosynthetic processes saturate at high $\mathrm{CO}_{2}$ concentrations (Franks et al., 2013; Körner, 2006). If NPP were to increase by nearly $50 \%$ over the 21 st century, as predicted by some ESMs, negative feedbacks on NPP would be expected at the ecosystem scale as previously discussed. 


\begin{tabular}{|l|r|c|c|}
\hline & $\begin{array}{c}\text { Abs. } \Delta \mathrm{C}_{\text {soil }} \\
{[\mathrm{Pg} \mathrm{C}]}\end{array}$ & $\begin{array}{c}\text { NPP } \\
{\left[\mathrm{Pg} \mathrm{C} \mathrm{yr}^{-1}\right]}\end{array}$ & $\begin{array}{c}\mathrm{C}_{\text {soil }} \\
{[\mathrm{Pg} \mathrm{C}]}\end{array}$ \\
\hline CESM1(BGC) & -4 & 46 & 575 \\
\hline NorESM1-ME & -16 & 47 & 617 \\
\hline BNU-ESM & 99 & 50 & 704 \\
\hline BCC-CSM1.1(m) & 203 & 58 & 930 \\
\hline HadGEM2-ES & 253 & 75 & 1121 \\
\hline IPSL-CM5A-MR & 15 & 84 & 1396 \\
\hline GFDL-ESM2G & 1 & 78 & 1411 \\
\hline CanESM2 & -51 & 65 & 1539 \\
\hline INM-CM4 & 76 & 68 & 1683 \\
\hline MIROC-ESM & -72 & 63 & 2565 \\
\hline MPI-ESM-MR & 211 & 93 & 3101 \\
\hline Benchmark range & & $46-73$ & $890-1660$ \\
\hline
\end{tabular}

Fig. 4. Metrics of ESM performance and benchmarks for soil $\mathrm{C}$ change (difference in 10-year means, 2090-2099 minus 19972006), net primary production (NPP; 10-year mean 1997-2006), and modern soil carbon pools (10-year mean 1997-2006). Benchmark data are shown in the bottom row. Blue cells indicate ESM outputs that fall below the benchmarks, yellow cells are consistent with benchmarks, and red cells are above the benchmarks. NPP data are from Ito (2011); modern soil carbon stocks are from Todd-Brown et al. (2013) and originally from (FAO/IIASA/ISRIC/ISSCAS/JRC, 2012).

In addition to potentially overestimating the 21 st century NPP response, ESMs likely overestimate the increase of SOC pools in response to increased carbon inputs. We found a strong relationship between the change in carbon inputs to soil and the change in ESM SOC (Fig. 6d). Even stronger relationships have been established between the spatial pattern of contemporary NPP and SOC in ESMs (Todd-Brown et al., 2013). However, there is empirical and theoretical evidence that increases in soil inputs, especially under elevated $\mathrm{CO}_{2}$, may have little effect on SOC stocks (Bader et al., 2013; Norby and Zak, 2011). $\mathrm{CO}_{2}$ fertilization often increases the labile fractions of plant litter and root exudation (Phillips et al., 2011; Schlesinger and Lichter, 2001). These inputs enter fast turnover carbon pools and are hypothesized to facilitate the decomposition of slow turnover pools through priming (Neill and Gignoux, 2006). All of these ESMs contain firstorder linear decomposition models of SOC and are thus unable to represent priming mechanisms (Wutzler and Reichstein, 2008). In addition, the availability of mineral surfaces (Six et al., 2002) may constrain the amount of SOC that can be stored in a given soil. These effects will likely weaken the coupling between NPP and SOC changes.

Finally, land use change can significantly affect NPP and land carbon storage. In one recent analysis with a subset of CMIP5 models, land use change resulted in terrestrial carbon losses of 25 to $205 \mathrm{Pg} \mathrm{C}$ compared with no land use change (Brovkin et al., 2013). This change is on the same order of magnitude as the 21 st century change in soil carbon simulated by many ESMs. Therefore land use change is a critical component of the terrestrial carbon cycle and is likely the

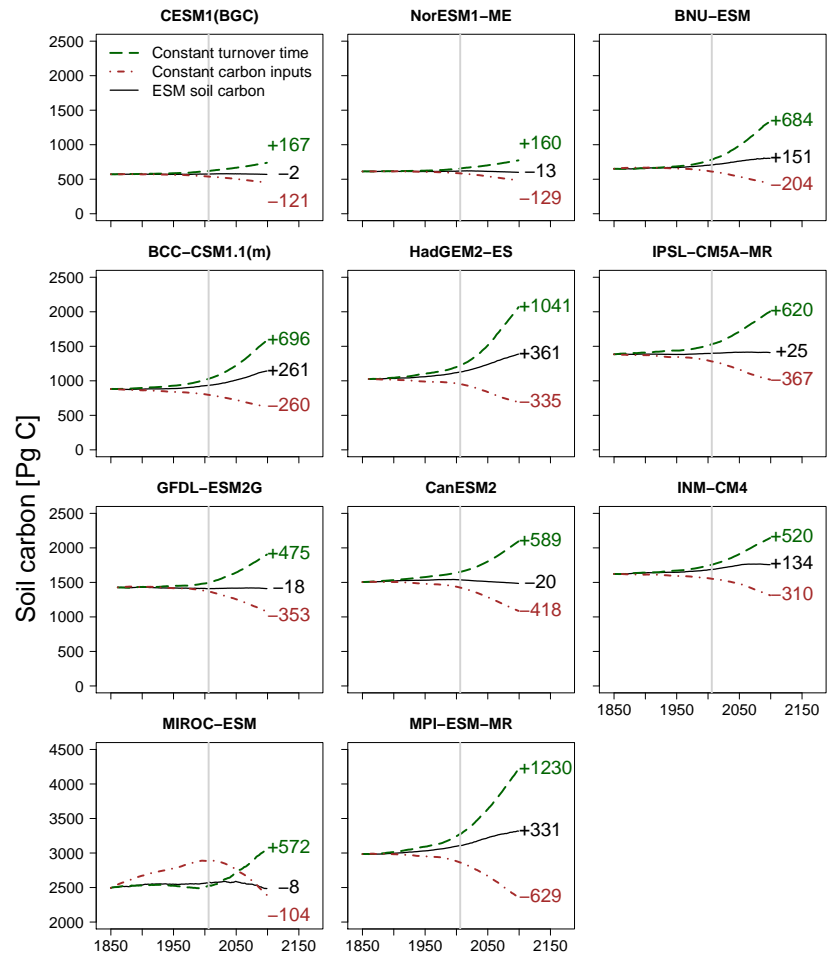

Fig. 5. Soil carbon over time (historical and RCP 8.5) under the "constant turnover time" and "constant carbon inputs" scenarios. The black solid line is the ESM-simulated global soil carbon stock with the net change from 1850 indicated in black text. The green dashed line is the soil carbon stock that would be predicted if turnover time were held constant at the 1850 value and soil inputs were allowed to evolve as predicted by the ESM, with the net change indicated in green text. The red dotted line is the soil carbon stock that would be predicted if carbon inputs were held constant at 1850 levels and the turnover time were allowed to evolve as predicted by the ESM, with the net change in red text. The vertical grey line at 2006 indicates where the historical experiment ends and the RCP 8.5 experiment begins.

driver of some of the variation in SOC not explained by parameterization and environmental variables in our analysis.

\subsection{Assessing reliability of SOC predictions}

One possible approach for narrowing the likely range of SOC predictions is to select estimates of SOC change from ESMs that are consistent with global benchmark data sets (Fig. 4). Two models fell within empirical estimates (BCCCSM-1.1(m) and CanESM2), and two additional models matched one empirical estimate and were close to the second (HadGEM2-ES and INM-CM4). Models consistent with the benchmarks did not have a markedly narrower range of simulated change in SOC; CanESM2 showed losses of $51 \mathrm{Pg} \mathrm{C}$, and BCC-CSM1.1(m) showed gains of $203 \mathrm{Pg} \mathrm{C}$. This wide range suggests that contemporary NPP and SOC benchmarks are not strong constraints on ESM simulations of future soil 

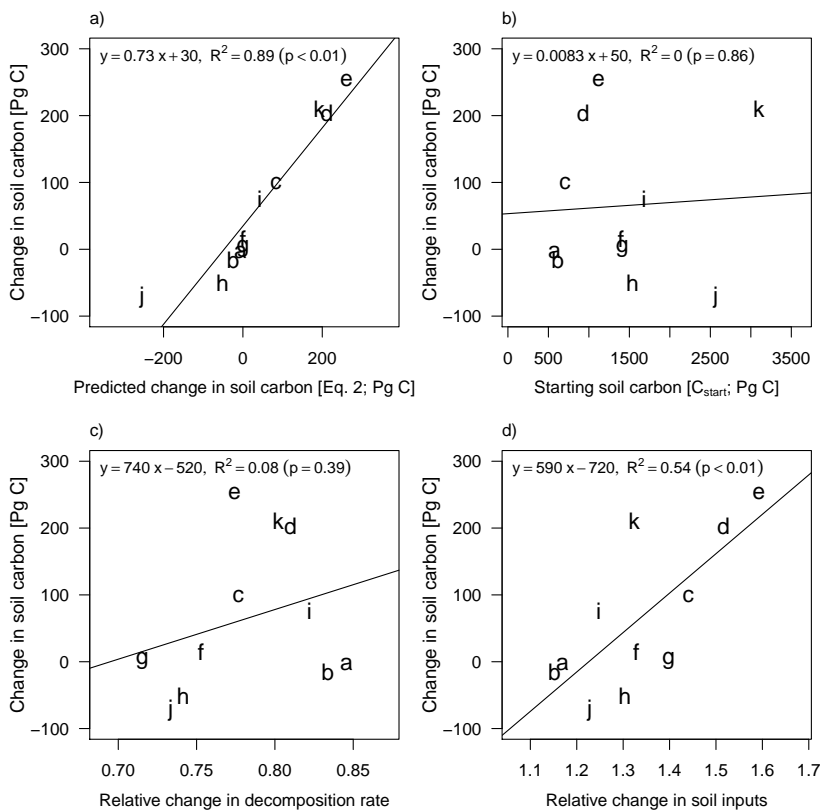

Fig. 6. Change in global soil organic carbon between 1997-2006 and 2090-2099 global means as a function of (a) Eq. (2), the relative change in input and decomposition rate times the initial soil carbon stock, $\left(\frac{1+\frac{\Delta I}{I_{\text {start }}}}{1+\frac{\Delta k}{k_{\text {start }}}}-1\right) \times C_{\text {start }},($ (b) starting soil carbon stock, $C_{\text {start }}$, (c) the inverse of the relative change in decomposition rate $(k), \frac{1}{1+\frac{\Delta k}{k_{\text {start }}}}$, and (d) relative change in soil inputs $(I), 1+\frac{\Delta I}{I_{\text {start }}}$. The models are represented as follows; a: CESM1(BGC), b: NorESM1ME, c: BNU-ESM, d: BCC-CSM1.1(m), e: HadGEM2-ES, f: IPSLCM5A-MR, g: GFDL-ESM2G, h: CanESM2, i: INM-CM4, j: MIROC-ESM, and k: MPI-ESM-MR.

carbon change. To have greater confidence in model projections, ESMs should probably match not only global benchmarks but also observed spatial patterns in NPP and SOC at biome- or grid scales (Todd-Brown et al., 2013).

The spatial pattern of SOC change provides another criterion for evaluating the likelihood of ESM predictions. All ESMs that predicted large SOC gains globally (i.e., greater than $75 \mathrm{PgC}$ ) also showed large gains in tundra and boreal biomes (greater than $46 \mathrm{Pg} \mathrm{C}$; Table 1). These models include BCC-CSM1.1(m) and INM-CM4, which were among the three models most consistent with benchmarking data. In contrast to these model predictions, empirical studies suggest that high-latitude soils are unlikely to serve as a longterm carbon sink (Schuur et al., 2009; Sistla et al., 2013). Even if tundra and boreal NPP increases substantially, SOC storage will likely be constrained by permafrost thawing, increases in fire frequency and severity, and high vulnerability of old SOC to decomposition under global change (Flannigan et al., 2009; Kasischke and Turetsky, 2006; Mack et al., 2004; Turetsky et al., 2011). Thus all of the ESMs predicting large gains in global SOC appear to depend on high levels of carbon storage in arctic ecosystems that may be more than offset
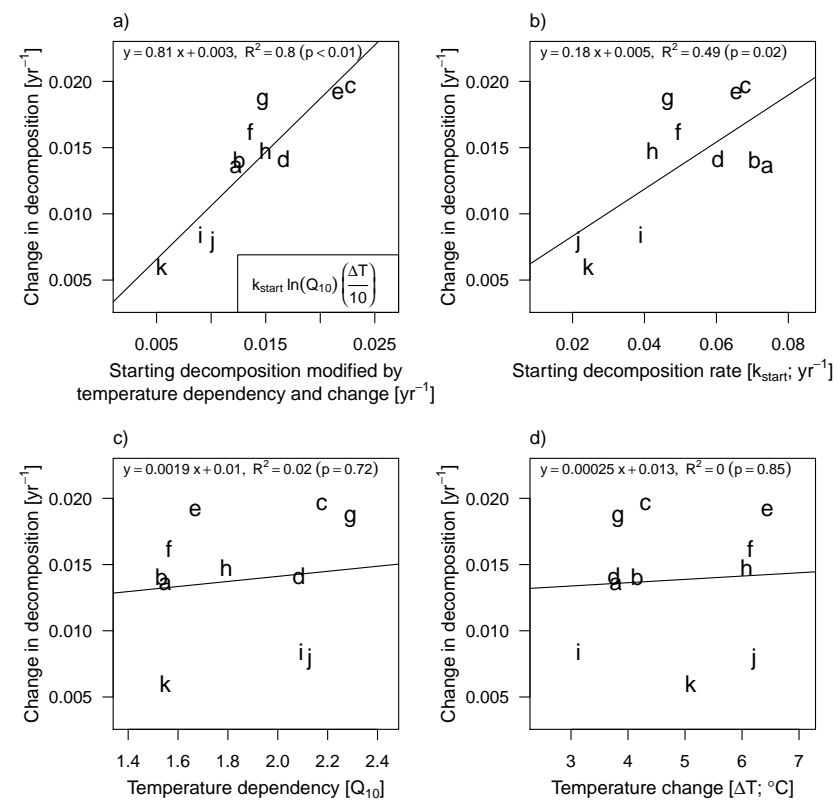

Fig. 7. Change in decomposition rate between 1997-2006 and 2009-2099 global means due to variation in (a) starting decomposition rate, $Q_{10}$, and soil temperature change from Eq. (7), $k_{\text {start }} \ln \left(Q_{10}\right)\left(\frac{\Delta T}{10}\right)$, (b) starting decomposition rate, $k_{\text {start }}$, (c) temperature dependency, $Q_{10}$, and (d) change in soil temperature, $\Delta T$. The models are represented as follows; a: CESM1(BGC), b: NorESM1-ME, c: BNU-ESM, d: BCC-CSM1.1(m), e: HadGEM2ES, f: IPSL-CM5A-MR, g: GFDL-ESM2G, h: CanESM2, i: INMCM4, j: MIROC-ESM, and k: MPI-ESM-MR.

by the release of permafrost carbon (Burke et al., 2012). This bias likely arises from the lack of permafrost carbon dynamics in current CMIP5 ESMs. Although some ESMs represent freeze-thaw dynamics, this broad-scale representation does not capture permafrost dynamics that include highly localized changes in hydrological conditions. ESMs that do not predict SOC accumulation in the arctic tend to predict SOC losses or much smaller gains at the global scale.

\section{Conclusions}

Our work shows that many current ESMs project substantial carbon sequestration potential in global soils over the $21 \mathrm{st}$ century. Although decomposition rates increase with climate warming, this effect is largely offset by $\mathrm{CO}_{2}$-driven increases in NPP and soil inputs. Unrecognized constraints on future NPP response or limits on the conversion of plant inputs to SOC could therefore substantially reduce soil carbon storage. In particular, constraints on NPP are uncertain because ecosystem-scale $\mathrm{CO}_{2}$ manipulations have not been carried out above $550 \mathrm{ppm}$, a value that may be exceeded by midcentury. As a result, our analysis calls into question the current majority of ESMs that show considerable SOC accumulation in the face of 21st century global change. Although a 
few ESMs are consistent with modern benchmark data sets, we conclude that there is considerable uncertainty surrounding future soil carbon storage in soils related to processes that are not represented within current ESMs.

New modeling efforts should consider quantifying constraints on the NPP response to global change and altering SOC sub-models to represent mechanisms responsible for SOC response to NPP change. For example, incorporating nutrient dynamics into ESMs could help constrain the NPP response to $\mathrm{CO}_{2}$ fertilization (Exbrayat et al., 2013; Piao et al., 2013; Thornton et al., 2009). Decomposition model structures could be updated to account for microbial priming effects (Wieder et al., 2013) and mineral-SOC interactions (Six et al., 2000, 2002; Torn et al., 1997; Wiesmeier et al., 2014). Biogeochemical responses in ESMs should be validated against global data sets (e.g., Luo et al., 2012; Todd-Brown et al., 2013) and empirical results from global change experiments across diverse ecosystems (Norby and Zak, 2011; Rustad et al., 2001). In addition to soil carbon stock and respiration measurements, isotopic data represent an underutilized constraint on the residence times of different soil carbon pools (Derrien and Amelung, 2011; Trumbore, 2009). These model development and analysis efforts will help ensure that policymakers can develop mitigation strategies for global change based on accurate projections of the global carbon cycle.

\section{Supplementary material related to this article is available online at http://www.biogeosciences.net/11/ 2341/2014/bg-11-2341-2014-supplement.pdf.}

Acknowledgements. We thank the US National Science Foundation (Advancing Theory in Biology and Decadal and Regional Climate Prediction using Earth System Models (EaSM) programs) and the US Department of Energy Office of Science Biological and Environmental Research (BER) for funding this research. We also acknowledge the World Climate Research Programme's Working Group on Coupled Modeling, which is responsible for CMIP, and we thank the model groups (listed in Table S1 of this paper) for producing and making available their model output. We thank the US Department of Energy's Program for Climate model Diagnosis and Intercomparison for providing coordinating support and leading development of software infrastructure in partnership with Global Organization for Earth System Science Portals. We would also like to thank Christian Reick for his contribution of the MPI-ESM simulations and manuscript review. Chris Jones was supported by the Joint UK DECC/Defra Met Office Hadley Centre Climate Programme (GA01101). Jerry Tjiputra also acknowledges the Biofeedback project of the Centre for Climate Dynamics.

Edited by: V. Brovkin
References

Anav, A., Friedlingstein, P., Kidston, M., Bopp, L., Ciais, P., Cox, P., Jones, C., Jung, M., Myneni, R., and Zhu, Z.: Evaluating the land and ocean components of the global carbon cycle in the CMIP5 Earth system models, J. Climate, 26, 6801-6843, doi:10.1175/JCLI-D-12-00417.1, 2013.

Arora, V. K., Boer, G. J., Friedlingstein, P., Eby, M., Jones, C. D., Christian, J. R., Bonan, G., Bopp, L., Brovkin, V., Cadule, P., Hajima, T., Ilyina, T., Lindsay, K., Tjiputra, J. F., and Wu, T.: Carbon-concentration and carbon-climate feedbacks in CMIP5 Earth system models, J. Climate, 26, 5289-5314, doi:10.1175/JCLI-D-12-00494.1, 2013.

Bader, M. K.-F., Leuzinger, S., Keel, S. G., Siegwolf, R. T. W., Hagedorn, F., Schleppi, P., and Körner, C.: Central European hardwood trees in a high- $\mathrm{CO}_{2}$ future: synthesis of an 8-year forest canopy $\mathrm{CO}_{2}$ enrichment project, J. Ecol., 101, 1509-1519, doi:10.1111/1365-2745.12149, 2013.

Bai, E., Li, S., Xu, W., Li, W., Dai, W., and Jiang, P.: A meta-analysis of experimental warming effects on terrestrial nitrogen pools and dynamics., New Phytol., 19, 431-440, doi:10.1111/nph.12252, 2013.

Billings, S. A., Lichter, J., Ziegler, S. E., Hungate, B. A., and Richter, D. de B.: A call to investigate drivers of soil organic matter retention vs. mineralization in a high $\mathrm{CO}_{2}$ world, Soil Biol. Biochem., 42, 665-668, doi:10.1016/j.soilbio.2010.01.002, 2010.

Brovkin, V., Boysen, L., Arora, V. K., Boisier, J. P., Cadule, P., Chini, L., Claussen, M., Friedlingstein, P., Gayler, V., van den Hurk, B. J. J. M., Hurtt, G. C., Jones, C. D., Kato, E., de NobletDucoudré, N., Pacifico, F., Pongratz, J., and Weiss, M.: Effect of anthropogenic land-use and land-cover changes on climate and land carbon storage in CMIP5 projections for the twentyfirst century, J. Climate, 26, 6859-6881, doi:10.1175/JCLI-D-1200623.1, 2013.

Burke, E. J., Jones, C. D., and Koven, C. D.: Estimating the permafrost-carbon climate response in the CMIP5 climate models using a simplified approach, J. Climate, 26, 4897-4909, doi:10.1175/JCLI-D-12-00550.1, 2012.

Carney, K. M., Hungate, B. A., Drake, B. G., and Megonigal, J. P.: Altered soil microbial community at elevated $\mathrm{CO}_{2}$ leads to loss of soil carbon, P. Natl. Acad. Sci., 104, 4990-4995, doi:10.1073/pnas.0610045104, 2007.

Chapin, F. S. and Eviner, V. T.: Biogeochemistry of terrestrial net primary production, in: Theatise on Geochemistry, vol. 8, edited by: Holland, H. D. and Turekian, K. K., 1-35, Pergamon, Oxford., 2007.

Cheng, W., Parton, W. J., Gonzalez-Meler, M. A., Phillips, R., Asao, S., McNickle, G. G., Brzostek, E., and Jastrow, J. D.: Synthesis and modeling perspectives of rhizosphere priming, New Phytol., 201, 31-44, doi:10.1111/nph.12440, 2014.

Ciais, P., Sabine, C., Bala, G., Bopp, L., Brovkin, V., Canadell, J., Chhabra, A., DeFries, R., Galloway, J., Heimann, M., Jones, C., Le Quéré, C., Myneni, R. B., Piao, S., and Thornton, P.: Carbon and Other Biogeochemical Cycles, in Climate Change 2013: The Physical Science Basis. Contribution of Working Group I to the Fifth Assessment Report of the Intergovernmental Panel on Climate Change, edited by: T. F. Stocker, Qin, D., Plattner, G.-K., Tignor, M., Allen, S. K., Boschung, J., Nauels, A., Xia, Y., Bex, 
V., and Midgley, P. M., p. 1535, Cambridge University Press, Cambridge, United Kingdom and New York, NY, USA, 2013.

Cook, F. J. and Orchard, V. A.: Relationships between soil respiration and soil moisture, Soil Biol. Biochem., 40, 1013-1018, doi:10.1016/j.soilbio.2007.12.012, 2008.

Cox, P. M., Pearson, D., Booth, B. B., Friedlingstein, P., Huntingford, C., Jones, C. D., and Luke, C. M.: Sensitivity of tropical carbon to climate change constrained by carbon dioxide variability, Nature, 494, 341-344, doi:10.1038/nature11882, 2013.

Davidson, E. A. and Janssens, I. A.: Temperature sensitivity of soil carbon decomposition and feedbacks to climate change, Nature, 440, 165-173, doi:10.1038/nature04514, 2006.

De Graaff, M.-A., Van Groenigen, K.-J., Six, J., Hungate, B., and Van Kessel, C.: Interactions between plant growth and soil nutrient cycling under elevated $\mathrm{CO}_{2}$ : a meta-analysis, Glob. Change Biol., 12, 2077-2091, doi:10.1111/j.1365-2486.2006.01240.x, 2006.

Derrien, D. and Amelung, W.: Computing the mean residence time of soil carbon fractions using stable isotopes: impacts of the model framework, Eur. J. Soil Sci., 62, 237-252, doi:10.1111/j.1365-2389.2010.01333.x, 2011.

Dungait, J. A. J., Hopkins, D. W., Gregory, A. S., and Whitmore, A. P.: Soil organic matter turnover is governed by accessibility not recalcitrance, Glob. Change Biol., 18, 1781-1796, doi:10.1111/j.1365-2486.2012.02665.x, 2012.

Exbrayat, J.-F., Pitman, A. J., Zhang, Q., Abramowitz, G., and Wang, Y.-P.: Examining soil carbon uncertainty in a global model: response of microbial decomposition to temperature, moisture and nutrient limitation, Biogeosciences, 10, 70957108, doi:10.5194/bg-10-7095-2013, 2013.

Falloon, P., Jones, C. D., Ades, M., and Paul, K.: Direct soil moisture controls of future global soil carbon changes: An important source of uncertainty, Global Biogeochem. Cy., 25, GB3010, doi:10.1029/2010GB003938, 2011.

FAO/IIASA/ISRIC/ISSCAS/JRC: Harmonized World Soil Database (version 1.10), FAO, Rome, Italy and IIASA, Laxenburg, Austria, 2012.

Fierer, N., Colman, B. P., Schimel, J. P., and Jackson, R. B.: Predicting the temperature dependence of microbial respiration in soil: A continental-scale analysis, Global Biogeochem. Cy., 20, GB3026, doi:10.1029/2005GB002644, 2006.

Flannigan, M. D., Krawchuk, M. A., de Groot, W. J., Wotton, B. M., and Gowman, L. M.: Implications of changing climate for global wildland fire, Int. J. Wildl. Fire, 18, 483, doi:10.1071/WF08187, 2009.

Fontaine, S., Bardoux, G., Abbadie, L., and Mariotti, A.: Carbon input to soil may decrease soil carbon content, Ecol. Lett., 7, 314 320, doi:10.1111/j.1461-0248.2004.00579.x, 2004.

Franks, P. J., Adams, M. A., Amthor, J. S., Barbour, M. M., Berry, J. A., Ellsworth, D. S., Farquhar, G. D., Ghannoum, O., Lloyd, J., McDowell, N., Norby, R. J., Tissue, D. T., and von Caemmerer, S.: Sensitivity of plants to changing atmospheric $\mathrm{CO}_{2}$ concentration: from the geological past to the next century, New Phytol., 197, 1077-1094, doi:10.1111/nph.12104, 2013.

Friedl, M. A., Sulla-Menashe, D., Tan, B., Schneider, A., Ramankutty, N., Sibley, A., and Huang, X.: MODIS Collection 5 global land cover: Algorithm refinements and characterization of new datasets, Remote Sens. Environ., 114, 168-182, doi:10.1016/j.rse.2009.08.016, 2010.
Friedlingstein, P., Cox, P., Betts, R., Bopp, L., von Bloh, W., Brovkin, V., Cadule, P., Doney, S., Eby, M., Fung, I., Bala, G., John, J., Jones, C., Joos, F., Kato, T., Kawamiya, M., Knorr, W., Lindsay, K., Matthews, H. D., Raddatz, T., Rayner, P., Reick, C., Roeckner, E., Schnitzler, K.-G., Schnur, R., Strassmann, K., Weaver, A. J., Yoshikawa, C., and Zeng, N.: Climate-carbon cycle feedback analysis: Results from the $\mathrm{C}^{4} \mathrm{MIP}$ model Intercomparison, J. Climate, 19, 3337-3353, doi:10.1175/JCLI3800.1, 2006.

Friend, A. D., Lucht, W., Rademacher, T. T., Keribin, R., Betts, R., Cadule, P., Ciais, P., Clark, D. B., Dankers, R., Falloon, P. D., Ito, A., Kahana, R., Kleidon, A., Lomas, M. R., Nishina, K., Ostberg, S., Pavlick, R., Peylin, P., Schaphoff, S., Vuichard, N., Warszawski, L., Wiltshire, A., and Woodward, F. I.: Carbon residence time dominates uncertainty in terrestrial vegetation responses to future climate and atmospheric $\mathrm{CO}_{2}$, P. Natl. Acad. Sci., 111, 3280-3285, doi:10.1073/pnas.1222477110, 2014.

Giorgi, F.: Climate change hot-spots, Geophys. Res. Lett., 33, L08707, doi:10.1029/2006GL025734, 2006.

Graven, H. D., Keeling, R. F., Piper, S. C., Patra, P. K., Stephens, B. B., Wofsy, S. C., Welp, L. R., Sweeney, C., Tans, P. P., Kelley, J. J., Daube, B. C., Kort, E. A., Santoni, G. W., and Bent, J. D.: Enhanced seasonal exchange of $\mathrm{CO}_{2}$ by northern ecosystems since 1960, Science, 341, 1085-1089, doi:10.1126/science.1239207, 2013.

Hoffman, F. M., Randerson, J. T., Arora, V. K., Bao, Q., Cadule, P., Ji, D., Jones, C. D., Kawamiya, M., Khatiwala, S., Lindsay, K., Obata, A., Shevliakova, E., Six, K. D., Tjiputra, J. F., Volodin, E. M., and $\mathrm{Wu}, \mathrm{T}$.: Causes and implications of persistent atmospheric carbon dioxide biases in Earth System Models, J. Geophys. Res.-Biogeo., 119, 141-162, doi:10.1002/2013JG002381, 2014.

Hofmockel, K. S., Zak, D. R., Moran, K. K., and Jastrow, J. D.: Changes in forest soil organic matter pools after a decade of elevated $\mathrm{CO}_{2}$ and $\mathrm{O}_{3}$, Soil Biol. Biochem., 43, 1518-1527, doi:10.1016/j.soilbio.2011.03.030, 2011.

Hoosbeek, M. and Scarascia-Mugnozza, G.: Increased litter build up and soil organic matter stabilization in a Poplar plantation after 6 years of atmospheric $\mathrm{CO}_{2}$ enrichment (FACE): Final results of POP-EuroFACE compared to other forest FACE experiments, Ecosystems, 12, 220-239, doi:10.1007/s10021-0089219-z, 2009.

Houghton, R. A.: Why are estimates of the terrestrial carbon balance so different?, Glob. Change Biol., 9, 500-509, doi:10.1046/j.1365-2486.2003.00620.x, 2003.

Hungate, B. A., Dijkstra, P., Wu, Z., Duval, B. D., Day, F. P., Johnson, D. W., Megonigal, J. P., Brown, A. L. P., and Garland, J. L.: Cumulative response of ecosystem carbon and nitrogen stocks to chronic $\mathrm{CO}_{2}$ exposure in a subtropical oak woodland., New Phytol., 200, 753-766, doi:10.1111/nph.12333, 2013.

Hungate, B. A., Van Groenigen, K.-J., Six, J., Jastrow, J. D., Luo, Y., De Graaff, M.-A., Van Kessel, C., and Osenberg, C. W.: Assessing the effect of elevated carbon dioxide on soil carbon: a comparison of four meta-analyses, Glob. Change Biol., 15, 20202034, doi:10.1111/j.1365-2486.2009.01866.x, 2009.

Ise, T. and Moorcroft, P. R.: The global-scale temperature and moisture dependencies of soil organic carbon decomposition: an analysis using a mechanistic decomposition model, Biogeochemistry, 80, 217-231, doi:10.1007/s10533-006-9019-5, 2006. 
Ito, A.: A historical meta-analysis of global terrestrial net primary productivity: are estimates converging?, Glob. Change Biol., 17, 3161-3175, doi:10.1111/j.1365-2486.2011.02450.x, 2011.

Jobbagy, E. G. and Jackson, R. B.: The vertical distribution of soil organic carbon and its relation to climate and vegetation, Ecol. Appl., 10, 423-436, 2000.

Kasischke, E. S. and Turetsky, M. R.: Recent changes in the fire regime across the North American boreal region - Spatial and temporal patterns of burning across Canada and Alaska, Geophys. Res. Lett., 33, L09703, doi:10.1029/2006GL025677, 2006.

Knutti, R. and Sedláček, J.: Robustness and uncertainties in the new CMIP5 climate model projections, Nat. Clim. Change, 3, 369373, doi:10.1038/nclimate1716, 2012.

Körner, C.: Plant $\mathrm{CO}_{2}$ responses: an issue of definition, time and resource supply, New Phytol., 172, 393-411, doi:10.1111/j.14698137.2006.01886.x, 2006.

Koven, C. D., Riley, W. J., and Stern, A.: Analysis of permafrost thermal dynamics and response to climate change in the CMIP5 Earth system models, J. Climate, 26, 1877-1900, doi:10.1175/JCLI-D-12-00228.1, 2013a.

Koven, C. D., Riley, W. J., Subin, Z. M., Tang, J. Y., Torn, M. S., Collins, W. D., Bonan, G. B., Lawrence, D. M., and Swenson, S. C.: The effect of vertically resolved soil biogeochemistry and alternate soil $\mathrm{C}$ and $\mathrm{N}$ models on C dynamics of CLM4, Biogeosciences, 10, 7109-7131, doi:10.5194/bg-10-7109-2013, 2013 b.

Koven, C. D., Ringeval, B., Friedlingstein, P., Ciais, P., Cadule, P., Khvorostyanov, D., Krinner, G., and Tarnocai, C.: Permafrost carbon-climate feedbacks accelerate global warming, P. Natl. Acad. Sci., 108, 14769-14774, doi:10.1073/pnas.1103910108, 2011.

Kuzyakov, Y., Friedel, J. K., and Stahr, K.: Review of mechanisms and quantification of priming effects, Soil Biol. Biochem., 32, 1485-1498, doi:10.1016/S0038-0717(00)00084-5, 2000.

Le Quéré, C., Raupach, M. R., Canadell, J. G., Marland, G., Bopp, L., Ciais, P., Conway, T. J., Doney, S. C., Feely, R. A., Foster, P., Friedlingstein, P., Gurney, K., Houghton, R. A., House, J. I., Huntingford, C., Levy, P. E., Lomas, M. R., Majkut, J., Metzl, N., Ometto, J. P., Peters, G. P., Prentice, I. C., Randerson, J. T., Running, S. W., Sarmiento, J. L., U., S., Sitch, S., Takahashi, T., Viovy, N., van der Werf, G. R., and Woodward, F. I.: Trends in the sources and sinks of carbon dioxide, Nat. Geosci., 2, 831836, doi:10.1038/ngeo689, 2009.

Lloyd, J. and Taylor, J. A.: On the temperature dependence of soil respiration, Funct. Ecol., 8, 315-323, 1994.

Luo, Y. Q., Randerson, J. T., Abramowitz, G., Bacour, C., Blyth, E., Carvalhais, N., Ciais, P., Dalmonech, D., Fisher, J. B., Fisher, R., Friedlingstein, P., Hibbard, K., Hoffman, F., Huntzinger, D., Jones, C. D., Koven, C., Lawrence, D., Li, D. J., Mahecha, M., Niu, S. L., Norby, R., Piao, S. L., Qi, X., Peylin, P., Prentice, I. C., Riley, W., Reichstein, M., Schwalm, C., Wang, Y. P., Xia, J. Y., Zaehle, S., and Zhou, X. H.: A framework for benchmarking land models, Biogeosciences, 9, 3857-3874, doi:10.5194/bg-93857-2012, 2012.

Luo, Y., Su, B., Currie, W. S., Dukes, J. S., Finzi, A., Hartwig, U., Hungate, B., Mc Murtrie, R. E., Oren, R., Parton, W. J., Pataki, D. E., Shaw, M. R., Zak, D. R., and Field, C. B.: Progressive nitrogen limitation of ecosystem responses to rising atmospheric carbon dioxide, Bioscience, 54, 731, doi:10.1641/00063568(2004)054[0731:PNLOER]2.0.CO;2, 2004.
Mack, M. C., Schuur, E. A. G., Bret-Harte, M. S., Shaver, G. R., and Chapin, F. S.: Ecosystem carbon storage in arctic tundra reduced by long-term nutrient fertilization, Nature, 431, 440-443, 2004.

Mahecha, M. D., Reichstein, M., Carvalhais, N., Lasslop, G., Lange, H., Seneviratne, S. I., Vargas, R., Ammann, C., Arain, M. A., Cescatti, A., Janssens, I. A., Migliavacca, M., Montagnani, L., and Richardson, A. D.: Global convergence in the temperature sensitivity of respiration at ecosystem level, Science, 329, 838-840, doi:10.1126/science.1189587, 2010.

Matthews, H. D., Eby, M., Weaver, A. J., and Hawkins, B. J.: Primary productivity control of simulated carbon cycle-climate feedbacks, Geophys. Res. Lett., 32, L14708, doi:10.1029/2005GL022941, 2005.

NASA Land Processes Distributed Active Archive Center (LP DAAC): Land Cover Type Yearly L3 Global 0.05Deg CMG (MCD12C1), USGS/Earth Resour. Obs. Sci. Center, Sioux Falls, South Dakota, available at: https://pdaac.usgs.gov/products/ modis_products_table/mcd12c1, 2008.

Neill, C. and Gignoux, J.: Soil organic matter decomposition driven by microbial growth: A simple model for a complex network of interactions, Soil Biol. Biochem., 38, 803-811, doi:10.1016/j.soilbio.2005.07.007, 2006.

Norby, R. J., DeLucia, E. H., Gielen, B., Calfapietra, C., Giardina, C. P., King, J. S., Ledford, J., McCarthy, H. R., Moore, D. J. P., Ceulemans, R., De Angelis, P., Finzi, A. C., Karnosky, D. F., Kubiske, M. E., Lukac, M., Pregitzer, K. S., ScarasciaMugnozza, G. E., Schlesinger, W. H., and Oren, R.: Forest response to elevated $\mathrm{CO}_{2}$ is conserved across a broad range of productivity, P. Natl. Acad. Sci., 102, 18052-18056, doi:10.1073/pnas.0509478102, 2005.

Norby, R. J., Warren, J. M., Iversen, C. M., Medlyn, B. E., and McMurtrie, R. E.: $\mathrm{CO}_{2}$ enhancement of forest productivity constrained by limited nitrogen availability, P. Natl. Acad. Sci., 107, 19368-19373, doi:10.1073/pnas.1006463107, 2010.

Norby, R. J. and Zak, D. R.: Ecological lessons from freeair $\mathrm{CO}_{2}$ enrichment (FACE) experiments, Annu. Rev. Ecol. Evol. Syst., 42, 181-203, doi:10.1146/annurev-ecolsys-102209144647, 2011.

Nowak, R. S., Ellsworth, D. S., and Smith, S. D.: Functional responses of plants to elevated atmospheric $\mathrm{CO}_{2}-$ do photosynthetic and productivity data from FACE experiments support early predictions?, New Phytol., 162, 253-280, doi:10.1111/j.1469-8137.2004.01033.x, 2004.

Pan, Y., Birdsey, R. A., Fang, J., Houghton, R., Kauppi, P. E., Kurz, W. A., Phillips, O. L., Shvidenko, A., Lewis, S. L., Canadell, J. G., Ciais, P., Jackson, R. B., Pacala, S. W., McGuire, A. D., Piao, S., Rautiainen, A., Sitch, S., and Hayes, D.: A large and persistent carbon sink in the world's forests, Science, 333, 988993, doi:10.1126/science.1201609, 2011.

Parton, W. J., Scurlock, J. M. O., Ojima, D. S., Gilmanov, T. G., Scholes, R. J., Schimel, D. S., Kirchner, T., Menaut, J., Seastedt, T., Garcia Moya, E., Kamnalrut, A., and Kinyamario, J. I.: Observations and modeling of biomass and soil organic matter dynamics for the grassland biome worldwide, Global Biogeochem. Сy., 7, 785-809, doi:10.1029/93GB02042, 1993.

Phillips, R. P., Finzi, A. C., and Bernhardt, E. S.: Enhanced root exudation induces microbial feedbacks to $\mathrm{N}$ cycling in a pine forest under long-term $\mathrm{CO}_{2}$ fumigation, Ecol. Lett., 14, 187-194, doi:10.1111/j.1461-0248.2010.01570.x, 2011. 
Phillips, R. P., Meier, I. C., Bernhardt, E. S., Grandy, A. S., Wickings, K., and Finzi, A. C.: Roots and fungi accelerate carbon and nitrogen cycling in forests exposed to elevated $\mathrm{CO}_{2}$, Ecol. Lett., 15, 1042-1049, doi:10.1111/j.1461-0248.2012.01827.x, 2012.

Piao, S., Sitch, S., Ciais, P., Friedlingstein, P., Peylin, P., Wang, X., Ahlström, A., Anav, A., Canadell, J. G., Cong, N., Huntingford, C., Jung, M., Levis, S., Levy, P. E., Li, J., Lin, X., Lomas, M. R., Lu, M., Luo, Y., Ma, Y., Myneni, R. B., Poulter, B., Sun, Z., Wang, T., Viovy, N., Zaehle, S., and Zeng, N.: Evaluation of terrestrial carbon cycle models for their response to climate variability and to $\mathrm{CO}_{2}$ trends, Glob. Change Biol., 19, 2117-2132, doi:10.1111/gcb.12187, 2013.

R Development Core Team: R: A Language and Environment for Statistical Computing, Vienna, Austria, 2012.

Riahi, K., Grübler, A., and Nakicenovic, N.: Scenarios of longterm socio-economic and environmental development under climate stabilization, Technol. Forecast. Soc. Change, 74, 887-935, doi:10.1016/j.techfore.2006.05.026, 2007.

Rustad, L., Campbell, J., Marion, G., Norby, R., Mitchell, M., Hartley, A., Cornelissen, J., and Gurevitch, J.: A meta-analysis of the response of soil respiration, net nitrogen mineralization, and aboveground plant growth to experimental ecosystem warming, Oecologia, 126, 543-562, doi:10.1007/s004420000544, 2001.

Schlesinger, W. H. and Lichter, J.: Limited carbon storage in soil and litter of experimental forest plots under increased atmospheric $\mathrm{CO}_{2}$, Nature, 411, 466-469, 2001.

Schuur, E. A. G., Bockheim, J., Canadell, J. G., Euskirchen, E., Field, C. B., Goryachkin, S. V, Hagemann, S., Kuhry, P., Lafleur, P. M., Lee, H., Mazhitova, G., Nelson, F. E., Rinke, A., Romanovsky, V. E., Shiklomanov, N., Tarnocai, C., Venevsky, S., Vogel, J. G., and Zimov, S. A.: Vulnerability of permafrost carbon to climate change: Implications for the global carbon cycle, Bioscience, 58, 701-714, doi:10.1641/B580807, 2008.

Schuur, E. A. G., Vogel, J. G., Crummer, K. G., Lee, H., Sickman, J. O., and Osterkamp, T. E.: The effect of permafrost thaw on old carbon release and net carbon exchange from tundra, Nature, 459, 556-559, doi:10.1038/nature08031, 2009.

Sistla, S. A., Moore, J. C., Simpson, R. T., Gough, L., Shaver, G. R., and Schimel, J. P.: Long-term warming restructures Arctic tundra without changing net soil carbon storage, Nature, 497, 615-618, 2013.

Six, J., Paustian, K., Elliott, E. T., and Combrink, C.: Soil structure and organic matter, Soil Sci. Soc. Am. J., 64, 681-689, doi:10.2136/sssaj2000.642681x, 2000.

Six, J., Conant, R. T., Paul, E. A., and Paustian, K.: Stabilization mechanisms of soil organic matter: Implications for C-saturation of soils, Plant Soil, 241, 155-176, 2002.
Talhelm, A. F., Pregitzer, K. S., and Zak, D. R.: Species-specific responses to atmospheric carbon dioxide and tropospheric ozone mediate changes in soil carbon, Ecol. Lett., 12, 1219-1228, doi:10.1111/j.1461-0248.2009.01380.x, 2009.

Taylor, K. E., Stouffer, R. J., and Meehl, G. A.: An overview of CMIP5 and the experiment design, B. Am. Meteorol. Soc., 93, 485-498, doi:10.1175/BAMS-D-11-00094.1, 2011.

Thornton, P. E., Doney, S. C., Lindsay, K., Moore, J. K., Mahowald, N., Randerson, J. T., Fung, I., Lamarque, J.-F., Feddema, J. J., and Lee, Y.-H.: Carbon-nitrogen interactions regulate climate-carbon cycle feedbacks: results from an atmosphereocean general circulation model, Biogeosciences, 6, 2099-2120, doi:10.5194/bg-6-2099-2009, 2009.

Todd-Brown, K. E. O., Randerson, J. T., Post, W. M., Hoffman, F. M., Tarnocai, C., Schuur, E. A. G., and Allison, S. D.: Causes of variation in soil carbon simulations from CMIP5 Earth system models and comparison with observations, Biogeosciences, 10, 1717-1736, doi:10.5194/bg-10-1717-2013, 2013.

Torn, M. S., Trumbore, S. E., Chadwick, O. A., Vitousek, P. M., and Hendricks, D. M.: Mineral control of soil organic carbon storage and turnover, Nature, 389, 170-173, 1997.

Trumbore, S.: Radiocarbon and soil carbon dynamics, Annu. Rev. Earth Planet. Sci., 37, 47-66, doi:10.1146/annurev.earth.36.031207.124300, 2009.

Turetsky, M. R., Kane, E. S., Harden, J. W., Ottmar, R. D., Manies, K. L., Hoy, E., and Kasischke, E. S.: Recent acceleration of biomass burning and carbon losses in Alaskan forests and peatlands, Nat. Geosci., 4, 27-31, 2011.

Wieder, W. R., Bonan, G. B., and Allison, S. D.: Global soil carbon projections are improved by modelling microbial processes, Nat. Clim. Change, 3, 909-912, 2013.

Wieder, W. R., Grandy, A. S., Kallenbach, C. M., and Bonan, G. B.: Integrating microbial physiology and physiochemical principles in soils with the MIcrobial-MIneral Carbon Stabilization (MIMICS) model, Biogeosciences Discuss., 11, 1147-1185, doi:10.5194/bgd-11-1147-2014, 2014.

Wiesmeier, M., Hübner, R., Spörlein, P., Geuß, U., Hangen, E., Reischl, A., Schilling, B., von Lützow, M., and Kögel-Knabner, I.: Carbon sequestration potential of soils in southeast Germany derived from stable soil organic carbon saturation, Glob. Change Biol., 20, 653-665, doi:10.1111/gcb.12384, 2014.

Wutzler, T. and Reichstein, M.: Colimitation of decomposition by substrate and decomposers - a comparison of model formulations, Biogeosciences, 5, 749-759, doi:10.5194/bg-5-749-2008, 2008. 